\title{
Inventariserend onderzoek arbeidsmarktmodule I-SEE project
}

Citation for published version (APA):

de Grip, A., Heijke, J. A. M., \& Vos, L. A. (1987). Inventariserend onderzoek arbeidsmarktmodule I-SEE project. Researchcentrum voor Onderwijs en Arbeidsmarkt, Faculteit der Economische Wetenschappen. ROA Reports No. 1 https://doi.org/10.26481/umarep.1987001

Document status and date:

Published: 01/01/1987

DOI:

10.26481/umarep.1987001

Document Version:

Publisher's PDF, also known as Version of record

\section{Please check the document version of this publication:}

- A submitted manuscript is the version of the article upon submission and before peer-review. There can be important differences between the submitted version and the official published version of record.

People interested in the research are advised to contact the author for the final version of the publication, or visit the DOI to the publisher's website.

- The final author version and the galley proof are versions of the publication after peer review.

- The final published version features the final layout of the paper including the volume, issue and page numbers.

Link to publication

\footnotetext{
General rights rights.

- You may freely distribute the URL identifying the publication in the public portal. please follow below link for the End User Agreement:

www.umlib.nl/taverne-license

Take down policy

If you believe that this document breaches copyright please contact us at:

repository@maastrichtuniversity.nl

providing details and we will investigate your claim.
}

Copyright and moral rights for the publications made accessible in the public portal are retained by the authors and/or other copyright owners and it is a condition of accessing publications that users recognise and abide by the legal requirements associated with these

- Users may download and print one copy of any publication from the public portal for the purpose of private study or research.

- You may not further distribute the material or use it for any profit-making activity or commercial gain

If the publication is distributed under the terms of Article $25 \mathrm{fa}$ of the Dutch Copyright Act, indicated by the "Taverne" license above, 
INVENTARISEREND ONDERZOEK ARBEIDSMARKTMODULE I-SEE PROJECT

ROA-R-1987/1
A. de Grip
J.A.M. Heijke
L.A. Vos

RESEARCHCENTRUM VOOR ONDERWIJS EN ARBEIDSMARKT

Faculteit der Economische Wetenschappen

Rijksuniversiteit Limburg

Maastricht, februari 1987 
INHOUDSOPGAVE

bladzi.jde

Voorwoord

Hoofdstuk 1: Inleiding

Hoofdstuk 2:

Arbeidsmarktdata

6

2.1.: Arbeidsmarlitdata studierichtingen Wetenschappelijk Onderwijs Arbeidsmarktdata beroepsklassen

$2.2 .:$ Arbeidsmarktdata van enkele specifieke beroepsgroepen

2.4.: Crisisgevoeligheid van het beroepsdomein

Hoofdstuk 3 :

Arbeidsmarktvoorspellingen

3.1.1.

Instroom schoolverlaters op de arbeidsmarkt

3.1.2.:

Vervangingsvraag

3.1.3.:

Ui tbreidingsvraag

Literatuurlijst

Bijlagen arbeidsmarktdata "I-SEE"-project:

Bijlage I

Arbeidsmarktdata met betrekking tot studierichtingen Wetenschappelijk Onderwijs

Bijlage II

Arbeidsmarktdata met betrekking tot beroepsklassen

Bijlage III

Arbeidsmarktdata met betrekking tot enkele specifieke beroepsgroepen 


\section{VOORWOORD}

In deze nota worden de resultaten gepresenteerd van een inventariserend onderzoek naar de mogelijkheden voor het leveren van expertise met betrekking tot de arbeidsmarktmodule voor een geautomatiseerd informatiesysteem over studierichtingen en beroepen. Vooralsnog is daarbij het accent gelegd op data die van belang kunnen zijn voor leerlingen in de eindexamenklassen van het VWo, die zich oriënteren op een universitaire studie.

Dit onderzoek is door het Researchcentrum voor Onderwijs en Arbeidsmarkt (ROA) van de Rijksuniversiteit Limburg verricht in opdracht van het Centrum voor Beleidsanalyse en Advies te Nijmegen. De opdracht is verstrekt in het kader van het I-SEE project dat wordt uitgevoerd door een projectgroep, waarvan de dagelijkse leiding berust bij dr. H.M. Pere, adjunct-directeur van het laatstgenoemde centrum.

Het onderzoek waarover hier wordt gerapporteerd, is uitgevoerd door drs. A. de Grip, met assistentie van L.A. Vos en stond onder leiding van dr. J.A.M. Heijke, directeur van het ROA.

De opzet van dit oriënterende onderzoek en met name de aard van de in eerste instantie te presenteren data is vastgesteld in naur overleg met A. Torben-Nielsen, die optrad als contactpersoon namens de I-SEE projectgroep. 
In dit rapport wordt verslag gedaan van een inventariserend onderzoek naar de mogelijkheden om gegevens over de situatie op de arbeidsmarkt te verstrekken, die van belang kunnen zijn voor de studie- c.q. beroepskeuze. Doelgroep daarbij is vooralsnog de groep leerlingen in de eindexamenklassen van het V.W.O., die zich orienteert op een studie in het Wetenschappelijk Onderwijs. Het onderzoek vond plaats in opdracht van het Centrum voor Beleidsanalyse en Advies te Nijmegen, in het kader van het I-SEE project dat als doel heeft te komen tot een geautomatiseerd informatiesysteem met betrekking tot de verschillende opleidingen en beroepen.

Deze nota heeft een overwegend praktisch karakter. Er zal derhalve niet expliciet worden ingegaan op de economische en sociologische theorievorming op het terrein van de relatie tussen onderwijs en arbeidsmarkt (zie hiervoor bijvoorbeeld Hammermesh \& Rees (1984) en Van Hoof \& Dronkers (1980)).

In dit oriënterende onderzoek zal geprobeerd worden inzicht te geven over een zo breed mogelijk terrein van studierichtingen, waarbinnen specifieke studierichtingen geplaatst kunnen worden. Gezien het korte tijdsbestek warin de informatie moest iorden opgeleverd, is tevens besloten te volstaan met het geven ran een summiere historische schets van vraag en aanbod ontwikkelingen en het beschrijven van de huidige arbeidsmarktsituatie. Zoals later in deze nota zal worden uiteengezet, mogen op basis van dergelijke cijfers niet zonder meer uitspraken worden gedaan over de arbeidsmarktperspectieven in de verschillende beroepen of studierichtingen. Aan het eind van deze nota zal verder worden ingegaan op de wijze warop dergelijke voorspellingen zouden kunnen plaatsvinden.

Geprobeerd is ook een zo breed mogelijk beeld te schetsen van de a ard van de beschilibare informatie. Daarom is het accent gelegd op het"verstrekken van arbeidsmarktgegevens voor het meest recente jaar warvoor dit thans mogelijk is: 1985 lop basis van de Arbeidskrachtentelling 1985). In principe zijn de gegevens die in deze nota voor dat jaar verstrekt worden ook te leveren voor de jaren 1981 en 1983 en voor wat betreft de bedrijfssectoren, beroepsklassen en -groepen, ook voor de jaren 1975, $197 i$ en 1979.

In een enkel geval wat het niet mogelijk het benodigde cijfermateriaal op de vereiste korte termijn van het CBS te krijgen. Voor zover dit het geval is, is volstaan met de corresponderende informatie voor 1981 .

In het volgende hoofdstuk zal een beschrijving worden gegeven van de voorhanden arbeidmarkt-data. De cijfers zijn daarbijuitgesplitst naar respectievelijk studierichting (paragraaf 2.1 ), beroepsklasse (paragraaf 2.2 ) en enkele specifieke beroepsgroepen (paragraaf 2.3). Paragraaf 2.4 beschrijft de aanpak die gevolgd zou kunnen worden om een indicator voor de mate van crisisgevoeligheid van een beroepsdomein te construeren. In hoofdstuk III zal worden ingegaan op de mogelijkheden die er zijn om te komen tot een middel-lange termijn voorspelling van de arbeidsmarktsituatie. Een dergelijke voorspelling is ons inziens de meest 
wenselijke informatie om een studie- of beroepskeuze (mede) op te baseren. 


\section{ARBEIDSMARKTDATA}

Pere (1986, p. 31) geeft een opsomming van een tiental kwantitatieve arbeidsmarkt-indicatoren die idealiter beschikbaar zouden moeten zijn voor de studie- of beroepskeuze:

1. de ontwikkeling van de omvang van het beroepsdomein;

2. het aandeel van het aantal werkenden binnen het domein in de totale beroepsbevolking;

3. het aandeel van verschillende categorieën beroepsbeoefenaren in het desbetreffende domein;

4. het opleidingsniveau en de opleidingsrichting van beroepsbeoefenaren;

5. de mate van crisisgevoeligheid van het beroepsdomein;

6. de leeftijdsopbouw van de beroepsbeoefenaars;

7. de te verwachten ontwikkeling van het domein;

8. de te verwachten toestroom van arbeidskrachten naar het domein;

9. mogelijke regionale verschillen in werkgelegenheid;

10. de te verwachten discrepantie tussen vraag en aanbod in het beroepsdomein.

De eerste zes indicatoren vereisen gegevens met betrekking tot de ontwikkelingen in het nabije verleden of over de huidige situatie. De laatste vier matstaven vereisen een toekomstroorspelling. Dergelijke voorspellingen kunnen vanzelfsprekend slechts worden gedaan, wanneer eerst een adequaat inzicht verkregen is in de situatie op de arbeidsmarlit op dit moment en in de bestaande dynamiek en de daaraan ten grondslag liggende processen. landaar dat in deze verkennende studie volstaan is met het beschrijven van de hujdige arbeidsmarlitsituatie en het geven van een summiere historische schets. Hiermee wordt tevens een inzicht gegeven in de mate van desaggregatie van de arbeidsmarktdata, die vooralsnog mogelijk is. De mate van crisisgevoeligheid van een bepald beroepsdomein is daarbij voorlopig buiten beschouwing gelaten. In paragraaf 2.4 zal zoals gezegd worden aangegeven op welke wijze hiervan een indicatie zou kunnen worden gegeven.

Bovenstaande opsomming is overigens geheel gericht op het traceren van de werkgelegenheidskansen in de verschillende beroepsrichtingen. Binnen de economische theorievorming wordt in de $\mathrm{zgn}$. "human-capital" theorie daarentegen vooral het belang van de te verwachten loonhoogte benadrukt als matstaf om een beroepskeuze op te baseren. Gegevens met betrekking tot de loonontwikkelingen vereisen echter andere data-bronnen dan de door ons geraadpleegde. Indien gewenst zou in een eventueel vervolgonderzoek ook gejnventariseerd kunnen worden in hoeverre dergelijke data aanwezig zijn.

Om het geheel enigszins overzichtelijk te houden hebben wij de data opgedeeld in drie aan elkaar te relateren invalshoeken, te weten 11:

1) Wij hanteren hierbij de door het CBS gebruikte terminologie "beroepsklassen" (totaal 86), onderverdeeld in 317 "beroepsgroepen". 
I. Arbeidsmarktdata

Onderwijs;

II. Arbeidsmarlitdata beroepsklassen;

III. Arbeidsmarktdata van enkele specifieke beroepsgroepen.

In de volgende paragrafen zullen deze drie invalshoeken achtereenvolgens worden besproken. Alvorens daartoe over te gaan, willen wij eerst nog ingaan op de kwaliteit van het gepresenteerde cijfermateriaal. Het merendeel van de data is zoals gezegd afkomstig uit de Arbeidskrachtentellingen 2 ). Vanzelfsprekend zijn de uitkomsten van deze enquêtes onderhevig aan een bepaalde onzekerheidsmarge. Figuur I geeft een indruk van de onder- en bovenmarges bij een $95 \%$-betrouwbaarheidsniveau van de Arbeidskrachtentellingen van 1981. Daar de Arbeidskrachtentelling 1983 en 1985 slechts een $3 \%$ steekproef waren, gelden voor de cijfers van deze tellingen nog grotere marges dan aangegeven in figuur I.

Figuur I: 95\% - betrourbaarheidsmarges Arbeidshrachtentelling 1981 .

Aantal

250
500
1000
2000
5000
10000
20000
50000

Ondergrens

$$
\begin{array}{r}
120 \\
310 \\
720 \\
1600 \\
4350 \\
9070 \\
18680
\end{array}
$$

47900
Bovengrens

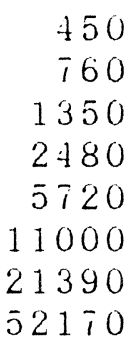

52170

\subsection{Arbeidsmarktdata studierichtingen Wetenschappelijk Onderwijs}

De Arbeidskrachtentellingen van 1981, 1983 en 1985 maken het mogelijk een beeld te schetsen van het aantal werkenden met een universitaire opleiding, uitgesplitst naar verschillende studierichtingen (waaronder MO-B studie). In Bijlage I wordt hiervan een overzicht gegeven. Zoals in hoofdstuk I werd opgemerkt, hebben wij ons hierbij beperkt tot het presenteren van de cijfers van 1985 .

2) De Arbeidskrachtentellingen zijn gebaseerd op tweejaarlijkse enquêtes onder $3-5 \%$ van de Nederlandse bevolking, telkens gehouden in de periode mart-mei. 
Voor 15 studierichtingen wordt achtereenvolgens de volgende informatie gegeven:

I. Het aantal werkenden

- absoluut

- in procenten van het totaal aantal werkenden

- in procenten van het aantal werkenden met een universitaire opleiding

II. De verdeling van het aantal werkenden over de verschillende beroepsklassen waarin men werkzaam is

III. Het relatieve aandeel in de werkgelegenheid in de desbetreffende beroepsklasse

- in procenten van het totaal aantal werkenden in de beroepsklasse

- in procenten van het aantal universitair geschoolden in de beroepsklasse

Il. Het aantal werklozen met de desbetreffende opleiding

- absoluut

- in procenten van het aantal werkenden met deze opleiding (1985)

- per 100 afgestudeerden in hetzelfde jaar $(1980,1984)$

- verkloosheid in enkele specifieke studierichtingen (1978, 1981 en 1984)

wanneer ook de overeenhomstige cijfers over $198 \mathrm{I}$ en 1983 worden berekend is het vanzelfsprekend eveneens mogelijk op ai deze punton enig inzicht te krijgen in de verschuivingen die in het nabije verleden hebben plaatsgevonden. Daarbij lian zich echter wel het probleem voordoen dat bepaalde veranderingen in deze cijfers statistisch niet-significant zijn. Bij de meeste studierichtingen speelt dit met name bi.j de punten II en III. Daarom hebben wij bij punt III geen percentage genoemd bij beroepsklassen waar een relatief gering deel van de werkenden met ie desbetreffende opleiding werkzaam is. Voor deze beroepsilassen zijn bij punt III ook geen cijfers gegeven 3 ).

Ook hebben we niet alle beroepsklassen opgesomd, waar mensen met de desbetreffende opleiding werken. Wanneer minder dan $1 \%$ in een bepalde beroepsklasse werkzaam is, wordt de beroepsklasse niet genoemd, omdat een dergelijk gering percentage ons inziens niet wijst op een reëel mogelijk beroepsperspectief voor iemand die de desbetreffende opleiding heeft gevolgd.

De bij punt II gepresenteerde data laten overigens duidelijk zien dat de meeste opleidingen niet voor éen enkel beroep opleiden. Dit geeft een cijfermatige onderbouwing aan eerdere constateringen van o.a. Van Hoof \& Dronkers (1980) en Pere (1986). Er kan echter wel geconstateerd worden dat een bepalde studierichting voor een boperkt aantal beroepen opleidt.

3) Daarbij is de volgende "vuistregel" gehanteerd. Alleen wanneer meer dan $5 \%$ in een beroepsklasse wertizaam is en het absolute aantal arbeidskrachten groter is dan 1000 , worden cijfers gegeven. 
Bij punt IV wordt een overzicht gegeven van de beschikbare werkloosheidscijfers. Het betreft hier cijfers van het Ministerie var Sociale Zaken en werkgelegenheid, op basis van de door de arbeidsbureaus geregistreerde werkloosheid. Deze gegevens zijn beschilkaar op kwartalbasis vanaf 1978. De indeling naar studierichting van deze cijfers stemt echter niet geheel overeen met de in de Arbeidskrachtentellingen gebruikte Standaard Onderwijs Indeling (S.O.I.), hetgeen in enkele gevallen het werkloosheidspercentage enigszins vertekent. Soortgelijke problemen doen zich voor bij de koppeling van de werkloosheidscijfers aan het aantal afgestudeerden. Dit laatste kengetal geeft overigens niet het werkloosheidspercentage van de schoolverlaters aan, maar louter het totaal aantal werklozen met een bepalde opleiding ten opzichte van 100 schoolverlaters in dezelfde studierichting.

\subsection{Arbeidsmarktdata beroepsklassen}

Vervolgens hebtien wij overeenkomstig de "wensenlijst" van Pere (1986) geprobeerd inzicht te krijgen in enkele aspecten van de beroepsklassen die in de bovenstaande analyse naar voren kwamen. In bijlage II wordt hiervan een overzicht gegeven. Voor de verschillende beroepsklassen wordt de rolgende informatie gegeven:

I. Het aantal werkenden in de beroepsklasse in 1971, 1981 en 1985

- absoluut

- in procenten van het totaal aantal fierkenden

II. Het aandeel van de verschillende leeftijdsgroepen in het aantal werlienden in de beroepsklasse in 1981 en 1985 4)

- procentuele aandee] leeftijdsgroepen

- indicator relatieve vervangingsbehoefte

- indicator absorptiegraad

III. Het aandeel van de verschillende opleidingsniveaus in het aantal werkenden in de beroepsklasse in 1981 en 1985

IV. Het percentage werkzaam bij de overhejd en overige kwartaire diensten. De cijfers van 1981 en 1985 hebben weer betrekking op de Arbeidskrachtentellingen in deze jaren. De cijfers van het aantal werkenden in 1971 zijn afkomstig uit de Volkstelling 19715 ).

Ook bij deze cijfers mag niet te veel waarde worden gehecht aan relatief geringe veranderingen. Vaak zijn deze statistisch niet significant.

4) Voor 1985 beschikken we op het moment alleen over informatie met betrekking tot de jongste leeftijdscategorie.

5) Deze cjjfers zijn min of meer vergelijkbaar, alhoewel er enige vertekening kan optreden door verschillen in nonresponse, e.d. 
Op basis van de verdeling van het aantal werkenden naar leeftijd hebben wij geprobeerd een tweetal indicatoren te construeren die enig inzicht geven in respectievelijk de (toekomstige) relatieve vervangingsbehoefte en de mate warin in het nabije verleden jongeren werk hebben gevonden in de desbetreffende beroepsklasse (de "absorptiegraad"). Deze matstaven zijn als volgt berekend:

Indicator relatieve vervangingsbehoefte:

$\%$ aandeel 50 - 64 jarigen in beroepsklasse

\%

$\%$ aandeel $50-64$ jarigen in totaal

Indicator absorptiegraad:

$\%$ áandeel < 30 jaar in beroepsklasse

$\%$ aandeel $<30$ jaar in totaal

Voor beide maatstaven geldt dat een waarde > 1 duidt op een grote relatieve toekomstige vervangingsbehoefte of een relatief hoge absorptiegraad in het nabije verleden. Bij een waarden van < 1 is de relatieve vervangingsbehoefte of de absorptiegraad verhoudingsgewijs laag.

Beide matstaven zijn vooralsnog echter ontoereikend. Zo kan de indicator voor de relatieve toekomstige vervangingsbehoefte een vertekend beeld geven van de te verwachten vervangingsvraag in een beroepsklasse, wanneer de groei van de werkgelegenheid in de desbetreffende beroepsklasse reeds geruime tijd stagneert. In dat geval is het immers uiterst twijfelachtig of uittredende oudere arbeidskrachten in de toekomst door jongeren vervangen zullen worden. Deze matstaf zou hiervoor moeten worden gecorrigeerd. Daarbij kan gedacht worden aan het "wegen" van de indicator met het indexcijfer van de relatieve werkgelegenheidsontwikkeling in de periode 1971 - 1981. Op deze wijze is de gecorrigeerde indicator relatieve vervangingsbehoefte (GIRV) berekend.

Ook bij de indicator van de absorptiegraad treedt er een vertekening op. Beroepsklassen, waar relatief veel hoger geschoolden werken zullen doorgaans minder werkenden onder de 30 jaar hebben, dan beroepsklassen waar relatief veel lager opgeleiden werkzam zijn. Deze vertekening ontstaat doordat de leeftijdsgroep< 30 jaar meer cohorten schoolverlaters omvat van de lagere dan van de hogere opleidingsniveaus. De gecorrigeerde absorptiegraad indicator (GAG) corrigeert voor deze vertekening 6).

Bij III wordt een indruk gegeven van de spreiding van het aantal werkenden in een beroepsklasse over de verschillende opleidingsniveaus. Ook hierbij hebben wij enkele percentages niet vermeld,

6) De GAG corrigeert de absorptiegraad voor het geringe aantal cohorten schoolverlaters van de hogere opleidingsniveaus in de groep < 30 jaar.

Daarbij zijn de volgende correctiefactoren toegepast: $14 / 12$ (voor aandeel HAVO/VWo-geschoolden), 14/11 (roor aandeel MBO-geschoolden), $14 / 8$ (voor aandeel HBOgeschoolden) en $14 / 6$ (voor aandeel wo-geschoolden). 
op basis van de vuistregel dat alleen cijfers worden gegeven wanneer het gaat om meer dan 1000 mensen en het percentage groter is dan 5 .

Tenslotte wordt aangegeven welk percentage van het aantal werkenden in een beroepsklasse werkzaam is bij de overheid of bij andere kwartaire diensten. Deze informatie zou kunnen worden uitgebreid met gegevens over het aantal werkenden in de verschillende bedrijfssectoren.

\subsection{Arbeidsmarktdata van enkele specifieke beroepsgroepen}

De beroepsklassen kunnen nog verder worden opgedeeld in beroepsgroepen. Ter aanvulling op de beroepsklasse-gegevens, hebben wij voor enkele beroepsgroepen waarin waarschijnlijk veel hoger geschoolden werkzaam zijn, gekeken naar de ontwikkeling van het aantal werkenden over de jaren 1971, 1981, 1983 en 1985. Daarbij worden zowel de absolute cijfers als het procentuele aandeel in het totaal aantal werkenden gegeven. Ook bij deze beroepsgroepscijfers zijn met name de vaak geringe veranderingen in het aantal werkenden in de jaren 1981,1983 en 1985 bij verschillende beroepsgroepen statistisch niet significant. Deze cijfers maken het bijvoorbeeld mogelijk voor de beroepsklasse geneeskundigen, etc. een nader onderscheid te maken tussen geneeskundigen, tandheelkundigen en diergeneeskundigen. Bij enkele beroepsklassen lbijvoorbeeld economen en accountants) bestat er geen verdere uitsplitsing in beroepsgroepen.

Een rechtstreelise koppeling van deze beroepsgroepscijfers aan de gegevens met betrekling tot de studierichtingen is helaas niet mogeli.jk, omdat de betrouwbaarhejd van het ci,jfermateriaal op dit lage aggregatieniveau te gering is.

\subsection{Crisisgevoeligheid van het beroepsdomein}

Het door ... ons gepresenteerde cijfermateriaal lat zien dat er op het niveau van de globale studierichtingen en beroepsklassen een aardige indruk kan worden gegeven van de eerste zes kwantitatieve indicatoren uit de opsomming van Pere. Alleen met betrekking tot de mate van crisisgevoeligheid van het beroepsdomein kon nog geen informatie worden verstrekt. De mogelijkheid hiertoe bestaat ons inziens echter wel. Zo zou bijvoorbeeld kunnen worden aangegeven in welke mate een bepalde beroepsklasse geconcentreerd is in een beperkt aantal sectoren (zie bijvoorbeeld Warnken (1986)). Een dergelijke concentratie-index geeft een indruk van de mate waarin een beroepsklasse gevoelig is voor het stagneren van de afzet in bepaalde sectoren. Ook zou kunnen worden gekeken welk aandeel een beroepklasse heeft in bepalde sectoren die relatief crisisgevoelig zijn. Dit laatste zou bijvoorbeeld door middel van een tijdreeksonderzoek kunnen worden oriderzocht. 


\section{ARBEIDSMARKTVOORSPELLINGEN}

De in deze nota gepresenteerde historische ontwikkeling van de werkgelegenheid in verschillende beroepsklassen of -groepen wordt soms te gemakkelijk geinterpreteerd als een goede arbeidsmarktmaatstaf om een beroeps- of studiekeuze op te baseren. Impliciet wordt dan uitgegaan van de meest simpele voorspeltechniek die er bestaat: een rechtlijnige extrapolatie op basis van een historische trend, in de zin van "wat tot nu toe goed is, zal dat ook in de toekomst zijn". In een aantal gevallen zal een dergelijke voorspelling ongetwijfeld vrij goed zijn. Het zwakke punt van een simpele rechtlijnige extrapolatie van een historische trend is echter dat een ombuiging van een ontwikkeling onmogelijk kan worden voorzien.

Bovendien moet beseft worden dat de omvang van de toekomstige werligelegenheid in een beroep een onvolledig beeld geeft van de werkgelegenheidsperspectieven. Daarbij speelt immers ook het aantal arbeidskrachten dat een baan zoekt in dat beroep een rol.

Deze bejde factoren maken een historische schets van de werkgelegenheidsontwikkeling een minder goede indicator voor een uit arbeidsmarkt-cogpunt verantworde beroeps- of studiekeuze.

Laten we nu eens kijken welke informatie we zouden moeten hebben voor een middellange-termijn vorspelling van de arbeidsmarlitsjtuatie van een bepaalde beroepsgroep. De toekomstige arbeidsmarktsjtuatie wordt bepaald door enerzijds de omvang van de vraag en anderzijds de omvang van het aanbod van arbeid. Lijtgangspunt daarbij is vanzelfsprekend de huidige vraag (aantal bezette arbeidsplaatsen + vacatures) en het huidige aanbod van arbeid (aantal werkenden + werklozen). De ontwikkeling van de vraag naar een bepalde beroepsgroep is afhankelijli van een drietal factoren:

- de contwikkejing van de afzet in de sectoren waarin deze arbejoskrachten werkzaam zijn;

- technologische en organisatorische veranderingen in de produktieprocessen binnen deze sectoren;

- verandering in de gemiddelde werktijd.

Deze drie factoren bepalen gezamenlijk de toekomstige vraag naar arbeidskrachten in de verschillende bedrijfssectoren. Daarnaast zijn met name de technologische veranderingen van invloed op de samenstelling van de vraag.

Ook de ontwikkeling van het arbeidsaanbod in een bepaalde beroepsgroep is afhankelijk van een aantal factoren:

- de uittrede van arbeidskrachten uit de beroepsbevolking, het zgn. "natuurli jke verloop";

- de netto-uitstroom van arbeidskrachten naar een andere beroepsgroep;

- de intrede van schoolverlaters; 
- de netto herintrede van andere arbeidskrachten vanuit de nietwerkende bevolking.

Het voorspellen van de toekomstige arbeidsmarktsituatie wordt daarbij bemoeilijkt door het bestaan van een wisselwerking tussen de ontwikkeling van de verschillende vraag en aanbodfactoren. Naarmate de voorspeltermijn langer is, zal deze wisselwerking vanzelfsprekend belangrijker zijn.

Hoewel de eerste twee bij de ontwikkeling van het arbeidsaanbod genoemde stroomfactoren strikt gezien aanbodfactoren zijn, bepalen beide factoren ook de "vervangingsvraag" naar arbeid. De bovengenoemde vraagontwikkeling staat daarentegen voor de "uitbreidingsvraag" 7).

De arbeidsmarktperspectieven voor de toekomstige instroom van nieuwe arbeidskrachten worden vanuit deze optiek bepald door enerzijds het aanbod van schoolverlaters en de herintrede van oudere arbeidskrachten en anderzijds de vervangings- en uitbreidingsvraag.

\subsection{Geplande werkwijze}

Tot slot van deze nota zullen we een globale schets geven van de wijze waarop we te werli zouden willen gaan bij het geven van arbejdsmarktprognoses in het kader van het I-SEE project. Daarbij stellen we als doel het voorspellen van de arbeidsmarktsituatie op het moment dat degenen die op basis van de gegeven informatie een studierichting kiezen, hun intrede doen op de arbeidsmarkt. Dit impliceert een middellange-termijn voorspelling voor een periode van 4 - 5 jaar. Achtereenvolgens zal worden ingegaan op het bepalen van de verwachte jnstroom van schoolverlaters, de verwachte vervangingsvraag en de verwachte uitbreidingsvrag.

\subsubsection{Instroom schoolverlaters op de arbeidsmarkt}

Het voorspellen van de instroom van schoolverlaters levert warschijnlijk de minste problemen op. Op basis van het huidige aantal leerlingen/studenten in de diverse leerjaren en het percentage voortijdige schoolverlaters in het recente verleden, kan een vrij betrouwbare schatting worden gemaakt van de instroom op de arbeidsmarkt naar studierichting. Eventueel zou men het te verwachten "drop-out" percentage kunnen bepalen door met behulp van regressievergelijkingen vast te stellen in hoeverre het voorti.jdig beëindigen van een opleiding in het verleden samenhing met bijvoorbeeld de situatie op de arbeidsmarkt.

Bij een studieduur van 4 - 5 jaar kan op deze wijze een vrij goede schatting worden gemaakt van de instroom van schoolverlaters op de arbeidsmarkt gedurende de voorspelperiode. Eventueel zou men ook nog rekening kunnen houden met het verwachte aantal eerste-jaars studenten in het eerstvolgende jaar, voor zover verwacht mag worden dat een deel hiervan nog binnen de voorspelperiode afstudeert. Dit verwachte aantal eerste-jaars studenten in de verschillende studierichtingen zou net zoals hjerboven bij

7) Deze uitbreidingsrrag lian overigens negatief zi.jn. 
het "drop-out" percentage werd voorgesteld kunnen worden voorspeld op basis van regressievergelijkingen, waarin de situatie op de arbeidsmarkt als verklarende variabele fungeert.

Op een soortgelijke wijze zou men het verwachte aantal eerstejaars in de verschillende studierichtingen kunnen voorspellen. Daar deze eerste-jaars studenten - zeker in het Wetenschappelijk Onderwijs - gedurende de voorspelperiode slechts in zeer geringe mate tot de arbeidsmarkt zullen toetreden, lijkt een dergelijke uitbreiding niet direct belangrijk.

Met name voor de lagere opleidingsniveaus zou ook een correctie gemakkt kunnen worden voor veranderingen in de doorstroom van schoolverlaters naar andere opleidingen. Deze correctie zou echter idealiter gebaseerd moeten worden op een partieel onderwijsmodel, waarin de doorstroomcoëfficiënten worden verklaard. Een dergelijke aanpak gat ons inziens in dit stadium echter te ver. wel is het mogelijk enkele strategische coëfficiënten door middel van trendextrapolatie op basis van historische ontwikkelingen te voorspellen. Deze methode is toegepast door het CPB (1986/II).

\subsubsection{Vervangingsvraag}

De verwachte omvang van de vervangingsvraag kan op twee manieren worden berekend. In de eerste plats kan het verlooppercentage worden vastgesteld. Dit zou vervolgens naar evenredigheid over de verschillende beroepsgroepen in een bedrijfssector moeten worden verdeeld. Dit latste is ons inziens echter weinig reëel. In de tweede plaats kan een schatting worden gemaakt van de vervangingsvraag op basis van het te verwachten natuurlijke verloop in de verschillende beroepsgroepen, uitgaande van het aantal arbeidskrachten in de hogere leeftijdscategorieën. Daarbij is het wenselijk deze cijfers aan te vullen met het te verwachten verloop van vrouwelijke arbeidskrachter in de lagere leefti.jdsgroepen. De verwachte vervangingsvraag voor een bepaalde beroepsgroep kan vervolgens naar evenredigheid worden verdeeld over de verschillende" opleidingsrichtingen die werkzaam zijn in de desbetreffende beroepsgroep.

\subsubsection{Uitbreidingsvraag}

Het voorspellen van de uitbreidingsvraag is ongetwijfeld de "crux" van een goede voorspelling van de arbeidsmarktsituatie op middellange termijn. We zouden daarbij als volgt te werk willen gaan. Als uitgangspunt voor de voorspelling kan de middellangetermijn voorspelling (CPB 1986/I) van de macro-economische werkgelegenheidsontwikkeling van het Centraal Planbureau fungeren (CPB 1985). Deze voorspelling is onderhevig aan allerlei onzekerheden met betrekking tot de ontwikkeling van de wereldhandel, wisselkoersen, arbeidsproduktiviteit, e.d. Om enig inzicht te krijgen in de gevolgen van deze onzelierheden voor de te verwachten arbejdsmarktsituatie voor de verschillende beroepen, zou gebruik gemakkt kunnen worden van de twee in de lange-termijn voorspelling door het $\mathrm{CPB}$ doorgerekende alternatieve scenario's ( $\mathrm{CPB} 1985$ ).

Met behulp van een zgn. "verdeelmodel" kan vervolgens een schatting worden gemaakt van de verwachte werkgelegenheid in 22 be- 
drijfssectoren. Een dergelijk verdeelmodel is gebaseerd op regressievergelijkingen waarin de werkgelegenheidsontwikkeling in een sector wordt verklaard vanuit een aantal macro-economische factoren (NEI 1986).

De aldus bepalde verwachte werkgelegenheid in de verschillende bedrijfssectoren dient vervolgens als uitgangspunt voor het schatten van de werkgelegenheid in de verschillende beroepsklassen. De meest eenvoudige wijze om dit te doen is de huidige samenstelling van de sectorale werkgelegenheid naar beroepsklasse te projecteren op de geschatte toekomstige sectorale werkgelegenheid. In dat geval wordt echter geen rekening gehouden met mogelijke toekomstige verschuivingen in de samenstelling van de sectorale werhgelegenheid, als gevolg van technologische ontwikkelingen, of eventuele afzetverschuivingen binnen de bedrijfssectoren. On hier enigszins rekening mee te houden zou men de verschuivingen in de beroepenstructuur binnen een bedrijfssector in het nabije verleden kunnen extrapoleren en vervolgens de aldus verkregen sectorale beroepenstructuur op de geschatte toekomstige sectorale werkgelegenheid kunnen projecteren. Een mogelijke verdere stap is het schatten van de toekomstige beroepenstructur. binnen een bedrjjfssector op basis van regressievergelijkingen, waarin de arbeidsproduktiviteit, de diffusie van technologische vernieuwingen, e.d. als verklarende variabelen fungeren.

Het sommeren van de werkgelegenhejd in een bepalde beroepsliasse over de verschillende bedrijfssectoren geeft de verwachte totale werkgelegenheid in de desbetreffende beroepsklasse.

Vervolgens moeten de beroepsklasse-verwachtingen worden toegerekend aan de verschillende opleidingsrichtingen. Ook hierbij kan in princjpe ook een lieuze worden gemakt uit de drie mogelijke verdeelmodelien. In de eerste plaats kan het huidige aandeel van de verschillende studierichtingen in de werkgelegenheid in een beroepsklasse worden geprojecteerd op de verwachte toekomstige werligelegenheid in de desbetreffende beroepen. Deze methode heeft als nadeel dat geen rekening gehouden wordt met eventuele substitutie- (tussen verschillende opleidingsrichtingen) of verdringingseffecten (tussen verschillende opleidingsniveaus). Van Hoof \& Dronkers (1980) wijzen op het belang van deze effecten. In de tweede plaats kan men ook hier de verschuivingen in de aandelen van de verschillende studierichtingen in het nabije verleden extrapoleren en de aldus verkregen opleidingsstructuur projecteren op de verwachte toekomstige werkgelegenheid in de beroepsklasse. Bij deze werkwijze wordt het voortzetten van bestaande substitutie en/of verdringingsprocessen ingecalculeerd. In de derde plaats zou geprobeerd kunnen worden de toekomstige opleidingsstructuur te bepalen met behulp van regressievergelijkingen, warin de diffussie van technologische vernieuwingen, de instroom van schoolverlaters naar opleidingsrichting en de arbeidsmarktsituatie als verklarende variabelen kunnen worden gebruikt. De totale uitbreidingsvaag naar arbeidskrachten met een bepalde studierichting verkrijgt men vervolgens door de aandelen in de werkgelegenheid in de verschillende beroepsklassen te sommeren.

Gezien de gewenste voorspeltermijn van 4 - 5 jaar is het voor-

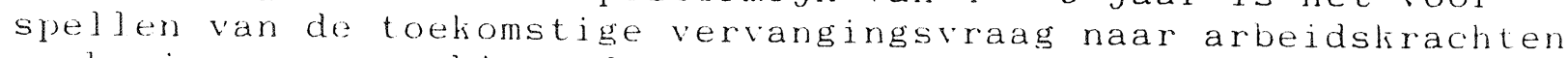
op basis van gecombineerde extrapolaties van de sectorale beroe- 
penstructuur en de opleidingsstructuur binnen de beroepsklassen de meest voor de hand liggende methode, te meer daar roorspellingen op basis van regressievergelijkingen vooralsnog aan belangrijke beperkingen met betrekking tot het voorhanden datamateriaal onderhevig zullen zijn. Een dergelijke aanpak maakt het echter wel mogelijk verschillende scenario's te hanteren, zoals bijvoorbeeld een "substitutie/verdringings-variant" (extrapolatie verschuiving opleidingsstructuur) en een "stabiele opleidingsstructuur variant". 


\section{LITERATUURLIJST}

- Centraal Planbureau (1985), De Nederlandse economie op lange termijn, S4, 's-Gravenhage.

- Centraal Planbureau (1986/I), Centraal Economisch Plan 1986, Staatsuitgeverij, 's-Gravenhage.

- Centraal Planbureau (1986/II), De onderwijsprognose 1986; werkdocument no. 9, 's-Gravenhage.

- Hamermesh, D.S.; A. Rees (1984), The economics of work and pay, Harper \& Row, New York.

- Hoof, J.J.; J. Dronkers (1980), Onderwijs en arbeidsmarkt: een verkenning van de relaties tussen onderwijs, arbeidsmarkt en arbeidssysteem, Van Loghum Slaterus, Deventer.

- Nederlands Economisch Instituut (1986), Een verkenning van de arbeidsmarkt naar beroep en opleiding, OSA-werkdocument nr. hi 1 .

- Pere, H.M. (1986), Arbeidsmarktvoorlichtingi Een voorstel voor interdisciplinaire opbouw, Centrum voor Beleidsanalyse en Advies, $\ i j m e g e n$.

- Warnken, J. (1986), Zur Entwicklung der "internen" Anpassungsfähigkeit der Berufe bis zum Jahre 2000. Projektionen unter den Annahmen der wachstumsszenarien der Prognos-Studie, Mitteilungen aus der Arbeitsmarkt- und Berufsforschung, no. 1, blz. 119-133. 


\section{BIJLAGEN ARBEIDSMARKTDATA "I-SEE"-PROJECT}

Bijlage I : Arbeidsmarktdata met betrekking tot studierichtingen Wetenschappelijk Onderwijs

Bijlage II : Arbeidsmarktdata met betrekking tot beroepsklassen

Bijlage III: Arbeidsmarktdata met betrekking tot enkele specifieke beroepsgroepen 
BI JLAGE I :

ARBEIDSMARLTDATA

MET

BETREKKING

TOT

STUDIERICHTINGEN

WETENSCHAPPELIJK ONDERWIJS (cijfers 1985)

Bron: CBS/RUA 
SOI-code bladzijde

- Opleiding tot onderwijzend personeel (MO-B)

$606 \quad 3$

$611 \quad 4$

- Letteren

616

6

- Theologie

621,622 ,

$623,629 \quad 7$

- wis- en natuurkunde

631

- Technisch onderwijs (algemeen)

636,639

11

- Opleiding tot architect e.d.

638

13

- Medische opleidingen

651

14

- Farmacologie

652

15

- Economische wetenschappen

661

16

- Econometrie en actuariaat

662

18

- Rechten

666

19

- Sociaal-cultureel onderwijs

671

21

- Huishoudkunde

681

23

- Kunstonderwijs

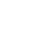

4

6


Opleiding tot onderwijzend personeel (MO-B)

I. Aantal werkenden in 1985

- absoluut: 14.300

- in $\%$ van totaal aantal werkenden: $0,28 \%$

- in \% van totaal aantal werkenden met een universitaire opleiding : $5,9 \%$

II. Verdeling van aantal werkenden naar beroepsklasse (\%)

1. Leerkrachten

2. Diverse wetenschappelijke en andere vakspecialisten

3. Statistici, wiskundigen, systeemanalisten en verwante vakspecialisten

4. Beeldende kunstenaars en reclame-ontwerpers

5. Musici, toneelspelers e.a. uitvoerende kunstenaars

6. Beleidvoerende en hogere leidinggevende functies (exclusief openbaar bestuur)

7. Diverse administratieve functies

III. Aandeel werkgelegenheid in beroepsklasse (\%)

in $\%$ van totaal aantal werkenden in beroepsklasse in \% van aantal universitair geschoolden in beroepsklasse

1. Leerkrachten

4

* Te gering percentage (zie noot 3 ) 


\section{LETTEREN}

I. Aantal werkenden in 1985

- absoluut aantal: 16.500

- in \% van totaal aantal werkenden: $0,32 \%$

- in $\%$ van totaal aantal werkenden met een universitaire opleiding : $6,8 \%$

II. Verdeling van aantal werkenden naar beroepsklasse (\%)

1. Leerkrachten

2. Diverse wetenschappelijke en andere vakspecialisten 18

3. Auteurs, journalisten e.d.

4. Diverse administratieve functies

5. Beleidvoerende en hogere leidinggevende functies (exclusief openbaar bestuur)

6. Secretaressen, typisten, ponstypisten e.d.

7. Zelfstandige groothandelaren e.d.

III. Aandeel werkgelegenheid in beroepsklasse (\%)

in $\%$ van totaal aantal werkenden in beroepsklasse in $\%$ van aantal universitair geschoolden in beroepsklasse
1. Leerkrachten

2. Diverse weten-

schappelijke en

andere vakspecia-

listen
4

20

3

\section{9}

IV. Aantal werklozen (cijfers in november/december):

Letteren (totaal):

- absaluut:

1978: 323

1979: 402

$1983: 1951$

$1980: 529$

$1984: 2322$

1981: 766

$1982: 1282$

1985: 2554

$1986: 2940$

- in \% van totaal aantal werkenden in opleidingsgroep in 1985: $15,5 \%$.

Indicator aantal werklozen per 100 afgestudeerden**:

$1980: 48,4$

$1984: 120,0$

- absoluut:

$\begin{array}{lrrr}1978 & \underline{1981} & \underline{1985} \\ 46 & & \\ 16 & 165 & 533 \\ 16 & 19 & 49 \\ 28 & 38 & 164 \\ 18 & 62 & 224 \\ 17 & 47 & 187 \\ & 19 & 79\end{array}$

- Nederlands

- Slavische talen

- Duits

- Engels

- Spaans 
5

- Scandinavische talen

- Latijn

- Grieks

- Wijsbegeerte

- Geschiedenis

- Archeologie

- Algemene taal- en literatuurwetenschappen

$\begin{array}{rrr}3 & 4 & 27 \\ 3 & 5 & 24 \\ 2 & 4 & 12 \\ 38 & 54 & 174 \\ 56 & 223 & 765 \\ 2 & 17 & 37 \\ 37 & 35 & 141\end{array}$

* Te gering percentage (zie noot 3 ).

* Hierbij is het aantal werklozen in respectievelijk november 1980 en december 1984 gedeeld door het aantal afgestudeerde studenten in de genoemde studierichting in het studiejaar $1980 / 1981$ respectievelijk 1984/1985. 


\section{THEOLOGIE}

I. Aantal werkenden in $\underline{1985}$

- absoluut aantal: 7.900

- in $\%$ van totaal aantal werkenden: $0,15 \%$

- in \% van totaal aantal werkenden met een universitaire opleiding : $3,3 \%$

II. Verdeling van aantal werkenden naar beroepsklasse (\%)

1. Bedienaars van de eredienst en verwante functies 71

2. Leerkrachten

3. Diverse wetenschappelijke e.a. vakspecialisten

4. Beleidvoerende en hogere leidinggevende functies (exclusief openbaar bestuur)

5. Economen

6. Secretaressen, typisten, ponstypisten e.d.

7. Diverse administratieve functies

8. Beroepsmilitairen

9. Dienstplichtige militairen

III. Aandeel werkgelegenheid in beroepsklasse (\%)

in $\%$ van totaal aantal werkenden in beroepsklasse in \% van aantal universitair geschoolden in beroepsklasse

1. Bedienaars van de eredienst en verwante functies

2. Leerkrachten

IV. Aantal werklozen (cijfers in november/december):

Theologie:

- absoluut:

1978: 67

1979: 69

$1983: 178$

1980: 71

$1984: 221$

1981: 84

1985: 206

$1982: 131$

$1986: 218$

- in \% van totaal aantal werkenden in opleidingsgroep in 1985: 2,6\%.

Indicator aantal werklozen per 100 afgestudeerden**:

$1980: 55,9$

$1984: 99,1$

* Te gering percentage (zie noot 3 ). 


\section{AGRARISCH ONDERWIJS}

I. Aantal werkenden in $\underline{1985}$

- absoluut aantal: 5.300

- in \% van totaal aantal werkenden: $0,10 \%$

- in \% van totaal aantal werkenden met een universitaire opleiding : $2,2 \%$

II. Verdeling van aantal werkenden naar beroepsklasse ( $\%$ )

1. Biologen, biochemici, landbouwkundigen en verwante vakspecialisten

2. Architecten, ingenieurs en verwante technici

3. Leerkrachten

4. Diverse wetenschappelijke e.a. vakspecialisten

5. Beleidvoerende en hogere leidinggevende functies (exclusief openbaar bestuur)

6. Directeuren en bedrijfsleiders groothandel

7. Boekhouders, kassiers en verwante functies

8. Diverse administratieve functies

9. Bedrijfsleiders land- en tuinbouw e.d.

10. Agrarische arbeiders

11. Winkelbedienden e.a. verkopers (exclusief vertegenwoordigers)

III. Aandeel werkgelegenheid in beroepsklasse ( $\%$ )

$\begin{array}{ll}\text { in } \% \text { van total } & \text { in \% van aantal univer- } \\ \text { aantal werkenden } & \text { sitair geschoolden in } \\ \text { in beroepsklasse } & \text { beroepsklasse }\end{array}$

1. Biologen, biochemici, landbouwkundigen en verwante vakspecialisten

IV. Aantal werklozen (cijfers in november/december):

Agrarisch onderwijs (totaal):

- absoluut:

1978: 162

$1979: 194$

$1983: 488$

$1980: 216$

$1984: 612$

1981: 285

$1985: 528$

$1982: 330$

$1986: 535$

- in $\%$ van totaal aantal werkenden in opleidingsgroep in 1985: $10,0 \%$ 。

Indicator aantal werklozen per 100 afgestudeerden**:

$1980: 65,7$

$1984: 94,7$

- absoluut: 
- Tropische landbouwwetenschappen

- Cultuurtechniek

$\begin{array}{rrr}29 & 36 & 70 \\ 8 & 33 & 71 \\ 13 & 17 & 21 \\ 16 & 20 & 51 \\ 17 & 24 & 47 \\ 15 & 16 & 26 \\ 11 & 23 & 53 \\ 20 & 33 & 47 \\ 4 & 10 & 19 \\ & & \\ 6 & 21 & 63 \\ 9 & 10 & 22\end{array}$

* Te gering percentage (zie noot 3 ). 


\section{WIS- EN NATUURKUNDE}

I. Aantal werkenden in 1985

- absoluut aantal: 22.500

- in \% van totaal aantal werkenden: $0,44 \%$

- in \% van totaal aantal werkenden met een universitaire opleiding : $9,3 \%$

II. Verdeling van aantal werkenden naar beroepsklasse (\%)

1. Leerkrachten 27

2. Schei-, natuurkundigen en verwante technici 17

3. Biologen, biochemici, landbouwkundigen en verwante vakspecialisten

4. Architecten, ingenieurs en verwante technici

5. Statistici, wiskundigen, systeemanalisten en verwante vakspecialisten

6. Diverse wetenschappelijke e.a. vakspecialisten

7. Beleidvoerende en hogere leidinggevende functies (exclusief openbaar bestuur)

8. Diverse administratieve functies

III. Aandeel werkgelegenheid in beroepsklasse (\%)

in \% van totaal aantal werkenden in beroepsklasse in \% van aantal universitair geschoolden in beroepsklasse

1. Leerkrachten

2. Schei-, natuurkundigen en verwante technici

3. Biologen, biochemici, landbouwkundigen en verwante vakspecialisten

4. Architecten, ingenieurs en verwante technici

5. Statistici, wiskundigen, systeemanalisten en verwante vakspecialisten

6. Diverse wetenschappelijke e.a. vakspecialisten

7. Beleidvoerende en hogere leidinggevende functies (exclusief openbaar bestuur) 
IV. Aantal werklozen (cijfers in november/december): Wis- en natuurkunde (totaal):

- absoluut: 1978: 1076 1979: 995

1980: 1067

1981: 1257 1982: 1607

1983: 2367

$1984: 2432$

$1985: 2233$

$1986: 2159$

- in $\%$ van totaal aantal werkenden in opleidingsgroep in 1985: $9,9 \%$.

Indicator aantal werklozen per 100 afgestudeerden**:

$1980: 92,1$

$1984: 147,5$

- absoluut:

$\underline{1978}$

$\underline{1981}$

1985

- Wiskunde

- Natuurkunde

- Biologie

99

112

139

278

461

133

513

- Scheikunde

6

383

10

119

286

1169

447

- Sterrenkunde

17

* Te gering percentage (zie noot 3 ). 
TECHNISCH ONDERWIJS (algemeen)

I. Aantal werkenden in 1985

- absoluut aantal: 35.300

- in \% van totaal aantal werkenden: $0,68 \%$

- in $\%$ van totaal aantal werkenden met een universitaire opleiding : $14,6 \%$

II. Verdeling van aantal werkenden naar beroepsklasse (\%)

1. Architecten, ingenieurs en.verwante technici $49 \%$

2. Beleidvoerende en hogere leidinggevende functies (exclusief openbaar bestuur) 15

- 3. Leerkrachten

4. Statistici, wiskundigen, systeemanalisten en verwante vakspecialisten

5. Diverse wetenschappelijke e.a. vakspecialisten

6. Schei-, natuurkundigen en verwante technici

7. Toezichthoudend- en leidinggevend produktie personeel

8. Directeuren en bedrijfsleiders groothandel

9. Economen

III. Aandeel werkgelegenheid in beroepsklasse (\%)

in $\%$ van totaal aantal werkenden in beroepsklasse in $\%$ van aantal universitair geschoolden in beroepsklasse

1. Architecten, ingenieurs en verwante technici

2. Beleidvoerende en hogere leidinggevende functies (exclusief openbaar bestuur)

3. Leerkrachten

4. Statistici, wiskundigen, systeemanalisten en verwante functies

IV. Aantal werklozen (cijfers in november/december):

Technisch Onderwijs (totaal):

- absoluut: 1978: 561 1979: 542

- in \% van totaal aantal werkenden in opleidingsgroep in $1985: 3,2 \%$. 
Indicator aantal werklozen per 100 afgestudeerden**:

$1980: 43,0$

$1984: 73,8$

- absoluut:

$\underline{1978} \quad \underline{1981} \quad \underline{1985}$

- Elektrotechniek

- Technische natuurkunde

$96 \quad \therefore 83$

79

- Chemische technologie

- Mijnbouw

50

28

37

15

- Metaalkunde

- Levensmiddeler

- Weg- en waterbouw

- Werktuigbouwkunde

- Vlieg tuigbouwkunde

- Scheepsbouwkunde

- Bouwkunde

$4 \quad 2$

386

598

* Te gering percentage (zie noot 3 ). 
OPLEIDING TOT ARCHITECT E.D.

I. Aantal werkenden in 1985

- absoluut aantal: 2.300

- in \% van totaal aantal werkenden: $0,04 \%$

- in \% van totaal aantal werkenden met een universitaire opleiding : $1,0 \%$

II. Verdeling van aantal werkenden naar beroepsklasse (\%)

1. Architecten, ingenieurs en. verwante technici 78

2. Leerkrachten

3. Beroepssportlieden, e.d.

4. Diverse wetenschappelijke e.a. vakspecialisten

5. Beleidvoerend en hoger leidinggevende functies bij openbaar bestuur

6. Zelfstandige winkeliers

III. Aandeel werkgelegenheid in beroepsklasse (\%)

$\begin{array}{ll}\text { in } \% \text { van total } & \text { in \% van aantal univer- } \\ \text { aantal werkenden } & \text { sitair geschoolden in } \\ \text { in beroepsklasse } & \text { beroepsklasse }\end{array}$

1. Architecten, ingenieurs en verwante technici

* Te gering percentage (zie noot 3 ). 


\section{MEDISCHE OPLEIDINGEN}

I. Aantal werkenden in 1985

- absoluut aantal: $3 \overline{6.500}$

- in \% van totaal aantal werkenden: $0,71 \%$

- in \% van totaal aantal werkenden met een universitaire opleiding : $15,1 \%$

II. Verdeling van aantal werkenden naar beroepsklasse (\%)

1. Genees-, tandheelkundigen, dierenartsen, verplegenden en verwante vakspecialisten

2. Leerkrachten

3. Biologen, biochemici, landbouwkundigen en verwante vakspecialisten

4. Beleidvoerende en hogere leidinggevende functies (exclusief openbaar bestuur)

5. Diverse wetenschappelijke e.a. vakspecialisten $n_{* k}$

III. Aandeel werkgelegenheid in beroepsklasse (\%)

$\begin{array}{ll}\text { in } \% \text { van total } & \text { in \% van aantal univer- } \\ \text { aantal werkenden } & \text { sitair geschoolden in } \\ \text { in beroepsklasse } & \text { beroepsklasse }\end{array}$

1. Genees-, tand-

heelkundigen,

dierenartsen,

verplegenden en

verwante vakspe-

cialisten

IV. Aantal werklozen (cijfers in november/december):

Medische opleidingen (totaal):

- absoluut:

1978: 296

1979: 421

$1983: 1849$

$1980: 592$

$1984: 2101$

1981: 847

$1985: 2230$

$1982: 1273$

$1986: 2186$

- in \% van totaal aantal werkenden in opleidingsgroep in 1985: 6, 1\%.

Indicator aantal werklozen per 100 afgestudeerden**:

$1980: 15,3$

$1984: 49,8$

- absoluut:

\begin{tabular}{|c|c|}
\hline 1978 & 1981 \\
\hline 243 & 713 \\
\hline 7 & 33 \\
\hline 46 & 101 \\
\hline
\end{tabular}

$\underline{1985}$

- Geneeskunde

- Tandheelkunde

- Diergeneeskunde

101

1752

385

93

* Te gering percentage (zie noot 3 ). 


\section{FARMACOLOGIE}

I. Aantal werkenden in 1985

- absoluut aantal: 1.800

- in \% van totaal aantal werkenden: $0,03 \%$

- in \% van totaal aantal werkenden met een universitaire opleiding : $0,7 \%$

II. Verdeling van aantal werkenden naar beroepsklasse (\%)

1. Genees-, tandheelkundigen," dierenartsen, verplegenden en verwante vakspecialisten

2. Biologen, biochemici, ·landbouwkundigen en verwante vakspecialisten

3. Leerkrachten

IV. Aantal werklozen (cijfers in november/december):

Farmacologie:

- absoluut:

1978: 29

$1983: 95$

$1979: 33$

$1984: 96$

$1980: 35$

$1985: 76$

1981: 59

1986: 90

$1982: 87$

- in \% van totaal aantal werkenden in opleidingsgroep in $1985: 4,2 \%$.

Indicator aantal werklozen per 100 afgestudeerden**:

$1980: 11,7$

$1984: 28,7$

* Te gering percentage (zie noot 3 ). 


\section{ECONOMISCHE WETENSCHAPPEN}

I. Aantal werkenden in 1985

- absoluut aantal: $2 \overline{1.300}$

- in $\%$ van totaal aantal werkenden: $0,41 \%$

- in \% van totaal aantal werkenden met een universitaire opleiding : $8,8 \%$

II. Verdeling van aantal werkenden naar beroepsklasse (\%)

1. Beleidvoerende en hogere leidinggevende functies (exclusief openbaar bestuur)

2. Accountants

3. Economen

4. Leerkrachten

5. Boekhouders, kassiers en verwante functies

6. Architecten, ingenieurs en verwante technici

7. Directeuren en bedrijfsleiders groothandel

8. Statistici, wiskundigen en systeemanalisten en verwante vakspecialisten

9. Uitvoerende hoofdambtenaren

10. Diverse wetenschappelijke e.a. vakspecialisten

11. Diverse administratieve functies

III. Aandeel werkgelegenheid in beroepsklasse (\%)

in \% van totaal aantal werkenden in beroepsklasse in \% van aantal universitair geschoolden in beroepsklasse

1. Beleidvoerende

en hogere lei-

dinggevende

functies (exclu-

sief openbaar

bestuur)

2. Accountants

3. Economen

4. Leerkrachten

5. Boekhouders,

kassiers en

verwante func-

ties

IV. Aantal werklozen (cijfers in november/december):

Economische wetenschappen (totaal):

- absoluut:

1978: 272

$1979: 246$

$1980: 272$

$1983: 739$

1981: 328

$1984: 697$

$1982: 472$

$1985: 630$

$1986: 638$

- in \% van total aantal werkenden in opleidingsgroep in 1985: 2,9\%. 
Indicator aantal werklozen per 100 afgestudeerden**:

$1980: 29,6$

$1984: 43,2$

- absoluut:

$\underline{1978} \quad \underline{1981} \quad \underline{1985}$

- Algemene economie

- Bedrijfseconomie

116

$\underline{1981}$

279

- Economische sociologie

125

186

- Fiscale economie

69
27

98

38

- Accountancy

0

14

- Bedrijfskunde

31

10

10

29

64

* Te gering percentage (zie noot 3 ). 


\section{ECONOMETRIE EN ACTUARIAAT}

I. Aantal werkenden in $\underline{1985}$

- absoluut aantal: 3.600

- in \% van totaal aantal werkenden: $0,07 \%$

- in $\%$ van totaal aantal werkenden met een universitaire opleiding : $1,5 \%$

II. Verdeling van aantal werkenden naar beroepsklasse (\%)

1. Architecten, ingenieurs en verwante technici 28

2. Economen

3. Beleidvoerende en hogere leidinggevende functies (exclusief openbaar bestuur)

4. Statistici, wiskundigen en systeemanalisten en verwante vakspecialisten

5. Leerkrachten

6. Diverse wetenschappelijke en andere vakspecialisten

7. Boekhouders, kassiers en verwante functies

8. Toezichthoudend- en leidinggevend administratief personeel

9. Diverse administratieve functies

10. Vertegenwoordigers, handelsagenten

$*$

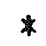

*

*

$\star$

III. Aandeel werkgelegenheid in beroepsklasse ( $\%$ )

$\begin{array}{ll}\text { in } \% \text { van total } & \text { in } \% \text { van aantal univer- } \\ \text { aantal werkenden } & \text { sitair geschoolden in } \\ \text { in beroepsklasse } & \text { beroepsklasse }\end{array}$

1. Architecten, ingenieurs en verwante technici

IV. Aantal werklozen (cijfers in november/december):

Econometrie en actuariaat:

- absoluut:
1978: 11
$1983: 43$
$1979: 25$
$1984: 38$
$1980: 13$
1985: 31
1981: 24
$1986: 27$

$1982: 29$

- in $\%$ van totaal aantal werkenden in opleidingsgroep in $1985: 0,9 \%$.

Indicator aantal werklozen per 100 afgestudeerden**:

$1980: 15,1$

$1984: 33,9$

* Te gering percentage (zie noot 3 ). 


\section{RECHTEN}

I. Aantal werkenden in 1985

- absoluut aantal: 28.200

- in \% van totaal aantal werkenden: $0,55 \%$

- in \% van totaal aantal werkenden met een universitaire opleiding : $11,7 \%$

II. Verdelingvan aantal werkenden naar beroepsklasse (\%)

1. Juristen

2. Beleidvoerende en hogere leidinggevende functies (exclusief openbaar bestuur)

3. Uitvoerende hoofdambtenaren

4. Leerkrachten

5. Boekhouders, kassiers en verwante functies

6. Diverse wetenschappelijke e.a. vakspecialisten

7. Diverse administratieve functies

8. Beleidvoerende en hogere leidinggevcende functies bij openbaar bestuur

9. Accountants

10. Auteurs, journalisten e.d.

11. Secretaressen, typisten, ponstypisten e.d.

III. Aandeel werkgelegenheid in beroepsklasse (\%)

in \% van totaal aantal werkenden in beroepsklasse in \% van aantal universitair geschoolden in beroepsklasse

1. Juristen

80

99

2. Beleidvoerende en hogere leidinggevende functies (exclusief openbaar bestuur)

2

12 1

0
12

40

3

33

IV. Aantal werklozen (cijfers in november/december):

Rechten:

- absoluut:

1978: 401

$1979: 418$

$1983: 1361$

$1980: 460$

$1984: 1660$

$1981: 592$

$1985: 1615$

$1982: 833$

1986: 1682

- in \% van totaal aantal werkenden in opleidingsgroep in $1985: 5,7 \%$. 
Indicator aantal werklozen per 100 afgestudeerden**:

1980: 29,8

$1984: 66,5$

- absoluut:

- Nederlands recht

- Bedrijfsrecht

149

- Privaatrecht

204

17

596

- Publiekrecht

129

40

66

- Strafrecht

82

33

61

- Fiscaal juridisch

14

- Notariaat

- Vrije juridische richting

13

12

11

62

13

* Te gering percentage (zie noot 3 ). 


\section{SOCIAAL-CULTUREEL ONDERWIJS}

I. Aantal werkenden in 1985

- absoluut aantal: 39.000

- in \% van totaal aantal werkenden: $0,76 \%$

- in \% van totaal aantal werkenden met een universitaire opleiding : $16,1 \%$

II. Verdeling van aantal werkenden naar beroepsklasse (\%)

1. Diverse wetenschappelijke e.a. vakspecialisten 53

2. Leerkrachten 24

3. Beleidvoerende en hogere leidinggevende functies (exclusief openbaar bestuur) 6

4. Diverse administratieve functies 5

5. Uitvoerende hoofdambtenaren *

6. Architecten, ingenieurs en verwante technici *

7. Auteurs, journalisten e.d. *

8. Boekhouders, kassiers en verwante functies *

III. Aandeel werkgelegenheid in beroepsklasse (\%)

in $\%$ van total
aantal werkenden $\%$ van aantal univer-
in beroepsklasse sitair geschoolden in

1. Diverse wetenschappelijke en andere vakspecialisten 19 67

2. Leerkrachten 3 18

3. Beleidvoerende en hogere leidinggevende functies (exclusief openbaar bestuur)

4. Diverse administratieve functies $\quad 1 \quad 35$

IV. Aantal werklozen (cijfers in november/december):

Sociale-cultureel onderwijs (totaal):

- absoluut: $1978: 1237$

$1979: 1493$

$1983: 4234$

$1980: 1750$

1984: 4866

1981: 2371

$1985: 5138$

1982: 3208

$1986: 5348$

- in \% van totaal aantal werkenden in opleidingsgroep in 1985: $13,2 \%$.

Indicator aantal werklozen per 100 afgestudeerden**:

1980: 86,6

1984: 182,9 
- absoluut:

- Politicologie

- Culturele anthropologie

- Westerse sociologie

- Niet westerse sociologie

- Sociale geografie

- Pedagogiek

- Andragologie

- Sociale pedagogiek

- Orthopedagogiek

- Psychologie (totaal)

- Klinische psychologie.

- Ontwikkelingspsychologie

- Beroepskeuzepsychologie

- Bedrijfspsychologie

- Sociale psychologie $\underline{1978}$

$\underline{1981}$

101

117

361

71

202

140

169

50

167

779

496

178

3

9

151 $\underline{1985}$

243

270

624

110

577

277

424

189

512

1081

828

384

14

59

239

* Te gering percentage (zie noot 3 ). 


\section{HUISHOUDKUNDE}

I. Aantal werkenden 1985

- absoluut aantal: $200 * * *$

- in \% van total aantal werkenden: 0,0

- in \% van totaal aantal werkenden met een universitaire opleiding : $0,1 \% * * *$

II. Verdeling van aantal werkenden naar beroepsklasse (\%)

1. Leerkrachten

III. Aandeel werkgelegenheid ín beroepsklasse (\%)

$$
\begin{aligned}
& \text { in } \% \text { van total } \\
& \text { aantal werkenden } \% \text { van aantal univer- } \\
& \text { in beroepsklasse } \\
& \text { beroepsklasse }
\end{aligned}
$$

1. Leerkrachten

0

0

IV. Aantal werklozen (cijfers in november/december):

Hui shoudkunde:

- absoluut:

1978: 22

1979: 22

1983: 71

$1980: 22$

1984: 80

1981: 34

$1985: 70$

$1982: 45$

$1986: 65$ - in \% van totaal aantal werkenden in opleidingsgroep
in 1985: 35.0\%.

Indicator aantal werklozen per 100 afgestudeerden**:

$1980: 115,8$

$1984: * * * *$

* Te gering percentage (zie noot 3 ).

** Statistisch niet significant.

**** Gegevens ontbreken. 


\section{KUNSTONDERWIJS}

I. Aantal werkenden in 1985

- absoluut aantal: 1.600

- in \% van totaal aantal werkenden: $0,03 \%$

- in \% van totaal aantal werkenden met een universitaire opleiding : $0,7 \%$

II. Verdeling van aantal werkenden naar beroepsklasse ( $\%$ )

1. Diverse wetenschappelijke e.a. vakspecialisten *

2. Leerkrachten *

3. Musici, toneelspelers.e.a. uitvoerende kunste-

4. Auteurs, journalisten e.d.

5. Beeldende kunstenaars en reclame-ontwerpers *

6. Diverse administratieve functies *

7. Verzekeringsagenten, makelaars, veilinghouders e.a. tussenpersonen

8. Diverse dienstverlenende functies *

IV. Aantal werklozen (cijfers in november/december):

Kunstonderwijs (totaal):

- absoluut: 1978: 54

$1979: 69$

$1983: 295$

1980: 96

$1984: 353$

$1981: 150$

$1985: 438$

$1982: 192$

$1986: 475$

- in \% van totaal aantal werkenden in opleidingsgroep in 1985: $27,4 \%$.

Indicator aantal werklozen per 100 afgestudeerden**:

1980: 89,7

$1984: 146,5$

- absoluut:

$\underline{1978}$

$\underline{1981}$

$\underline{1985}$

- Muziekwetenschappen

6

- Kunstwetenschappen

37

- Theaterwetenschappen

11

19

106

* Te gering percentage (zie noot 3 ). 
BIJLAGE I I

ARBEIDSMARKTDATA MET BETREKKING TOT BEROEPSKLASSEN

Bron: CBS/ROA 
- Schei-, natuurkundigen en

Beroepen

classifi-

catie-code* bladzijde verwante technici

- Architecten, ingenieurs en verwante technici

01

3

$02 / 03$

5

05

6

wante vakspecialisten

- Genees-, tandheelkundigen, .

dierenartsen, verplegenden

en verwante vakspecialisten

- Statistici, wiskundigen, systeemanalisten en verwante vakspecialisten

$06 / 07$

7

08

09

11

12

13

15

19

20

gevende functies bij openbaar bestuur

- Beleidvoerende en hogere leidinggevende functies

(exclusief openbaar bestuur)

- Toezichthoudend en leidinggevend administratief personeel

- Uitvoerende hoofdambtenaren

- Secretaressen, typisten en ponstypisten e.d.

- Boekhouders, kassiers en verwante functies

- Diverse administratieve functies

- Directeuren en bedrijfsleiders groothandel

- Zelfstandige groothandelaren en tussenpersonen

Vertegenwoordigers, handelsagenten

- Verzekeringsagenten, makelaars, veilinghouders en andere tussenpersonen

- Diverse dienstverlenende functies

- Toezichthoudende en leidinggevend produktiepersoneel

- Theologen

* CBS, 1978 en 1984 . 


\section{SCHEI-, NATUURKUNDIGEN EN VERWANTE TECHNICI}

I. Aantal werkenden:

- absoluut in 1971:26.900

1981: 33.500

$1985: 34.200$

- in * van totaal aantal werkenden: $1971: 0,56$

$1981: 0,70$

$1985: 0,66$

II. Aandeel leeftijdsgroepen in totaal aantal werkenden in beroepsklasse (\%):

$\begin{array}{ll}30 & \text { jaar } \\ 30-49 & \text { jaar } \\ 50-59 & \text { jaar } \\ 60-64 & \text { jaar }\end{array}$

$\frac{1981}{36}$

$\frac{1985 *}{37}$

Indicatoren:

Indicator relatieve vervangingsbehoefte**:

$1981: 0,94$

$1985:$

Gecorrigeerde indicator relatieve verrangingsbehoefte $(\mathrm{GIRV}) * * *$ :

$1981: 1,18$

1985:

Indicator absorptiegraad****:

$1981: 0,96$

$1985: 1,04$

Gecorrigeerde absorptiegraad (GAG)*****:

$1981: 1,23$

$1985: 1,26$

III. Aandeel opleidingscategorieën in totaal aantal werkenden in beroepsklasse $(\%)$ :

Universitair opgeleiden

$\frac{1981}{20}$

HBO-ers

30

MBO-ers

25

LBO-ers

HAVO/VWO-ers

MAlO-ers

Basis onderwijs

$\frac{1985}{15}$

15
33

30

8

\#

5

\#

IV. Aandeel werkzame personen bij de overheid en overige kwartaire diensten:

$1981: 43,0 \%$ 
Te gering percentage of a antal (zie paragraaf 2.2).

Overige gegevens nog niet beschikbaar.

**

Deze matstaf is als volgt bepaald:

\% a andeel 50 - 64 jarigen in beroepsklasse

\% a andeel $50-64$ jarigen in totaal

Wanneer deze matstaf groter is dan één, is de vervangingsbehoefte van de desbetreffende beroepsklasse op (middel) lange termijn waarschijnlijk relatief groot.

* * De indicator relatieve vervangingsbehoefte is hier gerogen met de index-cijfers van de relatieve werkgelegenheidsontwikkeling (zie paragraaf 2.2).

**** Deze matstaf is als volgt bepald:

$\%$ aandeel $<30$ jaar in beroepsklasse

\% a andeel< 30 jaar.in totaal

Wanneer deze matstaf groter is dan één, zijn in het nabije verleden relatief veel jongeren ( 30 jaar) in het desbetreffende beroepsklasse aangesteld.

*** De correctie die op de indicator absorptiegraad wordt toegepast is voor respectievelijk hO, HBO, MBO, HAVO/Mho en de rest gelijk aan $14 / 6,14 / 8,14 / 11,14 / 12$ en 1 vermenigvuldigd met hun andeel zoals genoemd onder III (zie noot
6 ) 


\section{ARCHITECTEN, INGENIEURS EN VERWANTE TECHNICI}

I. Aantal werkenden:

- absoluut in 1971: 133.700

1981: 179.100

1985: 179.000

- in \% van totaal aantal werkenden:1971: 2,79

$1981: 3,51$

$1985: 3,48$

II. Aandeel leeftijdsgroepen 'in totaal aantal werkenden in beroepsklasse $(\%)$ :

$\begin{array}{ll}<30 & \text { jaar } \\ 30-49 & \text { jaar } \\ 50-59 & \text { jaar } \\ 60-64 & \text { jaar }\end{array}$

$\frac{1981}{25} \quad \frac{1985 *}{20}$

Indicatoren:

Indicator relatieve vervangingsbehoefte**:

$1981: 1,11$

1985:

Gecorrigeerde indicator relatieve vervangingsbehoefte (GIRV)***:

$1981: 1,40$

1985 :

Indicator absorptiegraad****:

$1981: 0,67$

$1985: 0,58$

Gecorrigeerde absorptiegraad (GAG)*****:

$1981: 0,83$

$1985: 0,72$

III. Aandeel opleidingscategorieën in totaal aantal werkenden in beroepsklasse $(\%)$ :

Universitair opgeleiden

HBO-ers

$\mathrm{MBO}-\mathrm{ers}$

LBO-ers

HAVO/VWO-ers

MAVO-ers

Basis onderwijs

$\frac{1981}{10} \quad \frac{1985}{14}$

$33 \quad 33$

$45 \quad 43$

$6 \quad 5$

\# \#

$\#$

IV. Aandeel werkzame personen bij de overheid en overige kwartaire diensten:

$1981: 15,6 \%$

\# Te gering aantal of percentage (zie paragraaf 2.2 ). 


\section{BIOLOGEN, BIOCHEMICI, LANDBOUWKUNDIGEN EN VERWANTE VAK-}

\section{SPECIALISTEN}

I. Aantal werkenden:

- absoluut in 1971: 18.700

$1981: 27.500$

1985: 29.300

- in \% van totaal aantal werkenden: 1971: 0,39

$1981: 0,54$

$1985: 0,57$

II. Aandeel leeftijdsgroepen in totaal aantal werkenden in beroepsklasse $(\%)$ :

$\begin{array}{ll}<30 & \text { jaar } \\ 30-49 & \text { jaar } \\ 50-59 & \text { jaar } \\ 60-64 & \text { jaar }\end{array}$

\section{$\underline{1981}$}

45

43

10

60 - 64 jaar

Indicatoren:

Indicator relatieve vervangingsbehoef te**:

$1981: 0,75$

1985:

Gecorrigeerde indicator relatieve vervangingsbehoefte (GIRV)***:

$1981: 1.04$

$1985:$

Indicator absorptiegraad****:

$1981: 1,21$

$1985: 1,22$

Gecorrigeerde absorptiegraad (GAG)*****:

$1981: 1,69$

$1985: 1,71$

III. Aandeel opleidingscategorieën in totaal aantal werkenden in beroepsklasse (\%):

Universitair opgeleiden

HBO-ers

1981

22

MBO-ers

LBO-ers

HAVO/VhiO-ers

IV. Aandeel werkzame personen kwartaire diensten:

$1981: 38,2 \%$ $\frac{1985 *}{43}$

$$
\text { \# }
$$


GENEES-，TANDHEELKUNDIGEN，DIERENARTSEN， VERPLEGENDEN EN VERWANTE AKSPECIALISTEN

I. Aantal werkenden:

- absoluut in 1971: 141.530

1981: 222.000

$1985: 267.900$

- in \% van totaal aantal werkenden: 1971:2,95

$1981: 4,35$

$1985: 5,21$

II. Aandeel leeftijdgroepen in totaal aantal werkenden in beroepsklasse (\%):

$\begin{array}{ll}<30 & \text { jaar } \\ 30-49 & \text { jaar } \\ 50-59 & \text { jaar } \\ 60-64 & \text { jaar }\end{array}$ 1981

57

$\underline{1985 *}$

34

8

$\#$

Indicatoren:

Indicator relatieve vervangingsbehoefte**:

$1981: 0,55$

$1985:$

Gecorrigeerde indicator relatieve vervangingsbehoefte (GIRV)***:

1981: 0,81

$1985:$

Indicator absorptiegraad****:

$1981: 1,53$

$1985: 1,48$

Gecorrigeerde absorptiegraad (GAG)*****:

$1981: 1,83$

$1985: 1,74$

III. Aandeel opleidingscategorieën in totaal aantal werkenden in beroepsklasse (\%):

Universitair opgeleiden

HBO-ers

MBO-ers

LBO-ers

HAVO/VWO-ers

MAVO-ers

Basis onderwijs

\begin{tabular}{c}
1981 \\
\hline 14 \\
16 \\
56 \\
$\#$ \\
6 \\
6 \\
$\#$
\end{tabular}

\begin{tabular}{l}
1985 \\
\hline 12 \\
21 \\
54 \\
$\#$ \\
5 \\
$\#$ \\
$\#$
\end{tabular}


IV. Aandeel werkzame personen bij de overheid en overige kwartaire diensten:

1981: $11,5 \%$

\# Te gering aantal of percentage (zie paragraaf 2.2). 
STAT IST I CI, W I S KUNDI GEN,

\section{VAKSPECIALISTEN}

I. Aantal werkenden:

- absoluut in 1971: 17.900

$1981: 36.400$

$1985: 51.100$

- in \% van totaal aantal werkenden: 1971: 0,37

1981: 0,71

$1985: 0,99$

II. Aandeel leeftijdsgroepen in totaal aantal werkenden in beroepsklasse (\%):

$\begin{array}{ll}<30 & \text { jaar } \\ 30-49 & \text { jaar } \\ 50-59 \text { jaar } \\ 60-64 \text { jaar }\end{array}$

\begin{tabular}{c}
1981 \\
\hline 38 \\
55 \\
6 \\
$\#$
\end{tabular}

$\frac{1985 *}{36}$

Indicatoren:

Indicator relatieve vervangingsbehoefte**:

1981: 0,42

1985:

Gecorrigeerde indicator relatieve vervangingsbehoefte (GIRV)***:

1981:0,81

1985 :

Indicator absorptiegraad****:

$1981: 1,02$

$1985: 1,02$

Gecorrigeerde absorptiegraad (GAG)*****:

$1981: 1,27$

1985: 1,28

III. Aandeel opleidingscategorieën in totaal aantal werkenden in beroepsklasse (\%):

Universitair opgeleiden

HBO-ers

MBO-ers

LBO-ers

HAVO/VWO-ers

MAVO-ers

Basis onderwijs

\begin{tabular}{c}
1981 \\
\hline 17 \\
35 \\
29 \\
$\#$ \\
15 \\
$\#$ \\
$\#$
\end{tabular}

$\frac{1985}{15}$

38

29

\#

11 
IV. Aandeel werkzame personen bij de overheid en overige kwartaire diensten:

$1981: 18,7 \%$

\# Te gering aantal of percentage (zie paragraaf 2.2 ). 


\section{$\underline{\text { ECONOMEN }}$}

I. Aantal werkenden:

- absoluut in 1971: 7.500

1981: 13.700

$1985: 15.200$

- in \% van totaal aantal werkenden: 1971: 0,16

1981: 0,27

$1985: 0,30$

II. Aandeel leeftijdsgroepen in totaal aantal werkenden in beroepsklasse $(\%)$ :

\begin{tabular}{|c|c|c|}
\hline 30 & & \\
\hline 30 & jaar & 20 \\
\hline & jaar & \\
\hline 50 & jaar & 12 \\
\hline $60-6$ & jaar & $\neq$ \\
\hline
\end{tabular}

Indicatoren:

Indicator relatieve vervangingsbehoefte**:

$1981: 0,96$

1985 :

Gecorrigeerde indicator relatieve vervangingsbehoefte (GIRV) ***:

1981: 1,62

1985 :

Indicator absorptiegraad****:

$1981: 0,55$

$1985: 0,52$

Gecorrigeerde absorptiegraad (GAG)*****:

$1981: 0,85$

$1985: 0,74$

III. Aandeel opleidingscategorieën in totaal aantal werkenden ir: beroepsklasse $(\%)$ :

Universitair opgeleiden

HBO-ers

\begin{tabular}{|c|c|}
\hline 1981 & 1985 \\
\hline 47 & 35 \\
\hline 29 & 34 \\
\hline 14 & 20 \\
\hline \# & 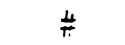 \\
\hline \# & $\#$ \\
\hline \# & \# \\
\hline$\#$ & $=$ \\
\hline
\end{tabular}

IV. Aandeel werkzame personen bij de overheid en overige kwartaire diensten:

$1981: 21,2 \%$

\# Te gering aantal of percentage (zie paragraaf 2.2). 


\section{ACCOUNTANTS}

I. Aantal werkenden:

- absoluut in 1971: 7.900

1981: 14.100

1985: 12.500

- in \% van total aantal werkenden: 1971: 0,16

$1981: 0,28$

$1985: 0,24$

II. Aandeel leeftijdsgroepen in totaal aantal werkenden in beroepsklasse (\%):

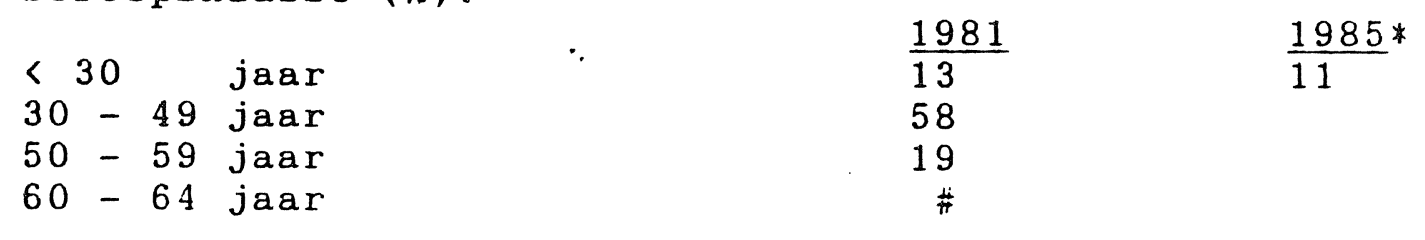

Indicatoren:

Indicator relatieve vervangingsbehoefte**:

$1981: 1,62$

1985 :

Gecorrigeerde indicator relatieve vervangingsbehoefte $(\mathrm{GIRV}) * * *$ :

$1981: 2,84$

1985:

Indicator absorptiegraad****:

$1981: 0,35$

$1985: 0,32$

Gecorrigeerde absorptiegraad (GAG)*****:

$1981: 0,50$

$1985: 0,45$

II . Aandeel opleidingscategorieën in totaal aantal werkenden in beroepsklasse (\%):

Universitair opgeleiden

HBO-ers

MBO-ers

LBO-ers

HAVO/VWO-ers

MAVO-ers

Basis onderwijs

$\begin{array}{cc}\frac{1981}{32} & \frac{1985}{38} \\ 33 & 27 \\ 23 & 26 \\ \# & \# \\ \# & \# \\ \# & = \\ \# & \mp\end{array}$

IV. Aandeel werkzame personen bij de overheid en overige kwartaire diensten:

$1981: \tau, 8 \%$

\# Te gering aantal of percentage (zie paragraaf 2.2 ). 


\section{JURISTEN}

I. Aantal werkenden:

- absoluut in 1971: 7.000

1981: 14.500

1985: 18.700

- in \% van totaal aantal werkenden: $1971: 0,15$

$1981: 0,28$

$1985: 0,36$

II. Aandeel leeftijdsgroepen in totaal aantal werkenden in beroepsklasse $(\%)$ :

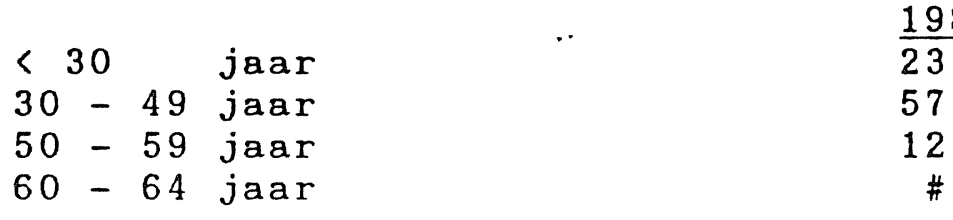

Indicatoren:

Indicator relatieve vervangingsbehoefte**:

$1981: 1,04$

1985 :

Gecorrigeerde indicator relatieve vervangingsbehoefte (GIRV)***:

$1981: 1,94$

1985 :

Indicator absorptiegraad****:

$1981: 0,62$

$1985: 0,61$

Gecorrigeerde absorptiegraad (GAG)*****:

$1981: 1,13$

$1985: 1,04$

III. Aandeel opleidingscategorieën in totaal aantal werkenden in beroepsklasse (\%):

Universitair opgeleiden

HBO-ers

MBO-ers

LBO-ers

HAVO/VWO-ers

MAVO-ers

Basis onderwijs

\begin{tabular}{cc}
1981 & 1985 \\
\hline 88 & 81 \\
$\#$ & 9 \\
$\#$ & $\#$ \\
$\#$ & $\#$ \\
$\#$ & $\#$ \\
$\#$ & $\#$ \\
$\#$ & $\#$
\end{tabular}

IV. Aandeel werkzame personen bij de overheid en overige kwartaire diensten:

$1981: 43,5 \%$

\# Te gering aantal of percentage (zie paragraaf 2.2). 


\section{LEERKRACHTEN}

I. Aantal werkenden:

- absoluut in 1971: 156.700

1981: 265.200

1985: 276.000

- in \% van total aantal werkenden: 1971: 3,27

1981: 5,19

$1985: 5,37$

II. Aandeel leeftijdsgroepen in totaal aantal werkenden in beroepsklasse (\%):

$\begin{array}{llccc}<30 & \text { jaar } & \frac{1981}{31} & \underline{1985 *} \\ 30-49 \text { jaar } & 56 & \\ 50-59 \text { jaar } & 12 & \\ 60-64 \text { jaar } & \#\end{array}$

Indicatoren:

Indicator relatieve vervangingsbehoefte**:

$1981: 0,84$

1985 :

Gecorrigeerde indicator relatieve vervangingsbehoefte (GIRV)***:

$1981: 1,33$

$1985:$

Indicator absorptiegraad $* * * *$ :

$1981: 0,83$

$1985: 0,65$

Gecorrigeerde absorptiegraad (GAG)*****:

$1981: 1,14$

$1985: 0,93$

II Aandeel opleidingscategorieën in totaal aantal werkenden in beroepsklasse (\%):

Universitair opgeleiden

HBO-ers

$\frac{1981}{17} \quad \frac{1985}{19}$

MBO-ers

LBO-ers

HAVO/VWO-ers

MAVO-ers

Basis onderwijs

69

11

\#

$¥$

$\#$

71

IV. Aandeel werkzame personen bij de overheid en overige kwartaire diensten:

$1981: 97,5 \%$

\# Te gering aantal of percentage (zie paragraaf 2.2 ). 
AUTEURS, JOURNALISTEN E.D.

I. Aantal werkenden:

- absoluut in 1971: 7.800

1981: 17.200

1985: 20.100

- in $\%$ van totaal aantal werkenden: $1971: 0,16$

1981: 0,34

$1985: 0,39$

II. Aandeel leeftijdsgroepen in totaal aantal werkenden in beroepsklasse (\%):

$\begin{array}{llll}<30 & \text { jaar } & \frac{1981}{26} & \underline{1985 *} \\ 30-49 & \text { jaar } & 56 & \\ 50-59 \text { jaar } & 12 & \\ 60-64 \text { jaar } & \#\end{array}$

Indicatoren:

Indicator relatieve vervangingsbehoefte**:

$1981: 1,06$

1985 :

Gecorrigeerde indicator relatieve vervangingsbehoefte (GIRV)***:

$1981: 2,25$

$1985:$

Indicator absorptiegraad****:

$1981: 0,69$

$1985: 0,70$

Gecorrigeerde absorptiegraad (GAG)*****:

$1981: 0,82$

$1985: 0,83$

II. Aandeel opleidingscategorieën in totaal aantal werkenden in beroepsklasse (\%):

Universitair opgeleiden

HBO-ers

$\frac{1981}{10}$

MBO-ers

30

LBO-ers

18

HAVO/VWO-ers

MAVO-ers

Basis onderwijs

29

29

6

\begin{tabular}{c}
1985 \\
\hline 11 \\
35 \\
20 \\
$\#$ \\
24 \\
7 \\
$\neq$
\end{tabular}

IV. Aandeel werkzame personen bij de overheid en overige kwartaire diensten:

1981: $29,7 \%$

\# Te gering aantal of percentage (zie paragraaf 2.2 ). 


\section{DIVERSE WETENSCHAPPELIJKE EN ANDERE VAKSPECIALISTEN}

I. Aantal werkenden:

- absoluut in 1971: 38.900

1981: 92.100

1985: 110.700

- in $\%$ van totaal aantal werkenden: 1971: 0,81

$1981: 1,80$

$1985: 2,15$

II. Aandeel leeftijdsgroepen in totaal aantal werkenden in beroepsklasse (\%):

$\begin{array}{lllll}<30 & \text { jaar } & . & \frac{1981}{33} & \frac{1985 *}{25} \\ 30-49 \text { jaar } & & 56 & \\ 50-59 \text { jaar } & & 10 & \\ 60-64 \text { jaar } & & \frac{*}{\pi}\end{array}$

Indicatoren:

Indicator relatieve vervangingsbehoefte**:

$1981: 0,70$

1985:

Gecorrigeerde indicator relatieve vervangingsbehoefte (GIRV)***:

$1981: 1,56$

1981:

Indicator absorptiegraad****:

$1981: 0,89$

$1985: 0,71$

Gecarrigeerde absorptiegraad (GAG)*****:

$1981: 1,24$

1985: 1,00

II . Aandeel opleidingscategorieën in totaal aantal werkenden in beroepsklasse (\%):

$\begin{array}{lcc}\text { Universitair opgeleiden } & \frac{1981}{24} & \frac{1985}{28} \\ \text { HBO-ers } & 41 & 47 \\ \text { MBO-ers } & 22 & 15 \\ \text { LBO-ers } & \# & \# \\ \text { HAVO/VWO-ers } & 5 & \# \\ \text { MAVO-ers } & \# & \# \\ \text { Basis onderwijs } & \# & \$\end{array}$

IV. Aandeel werkzame personen bij overheid en overige kwartaire diensten:

$1981: 72,6 \%$

\# Te gering aantal of percentage (zie paragraaf 2.2). 
BELEIDVOERENDE- EN HOGERE LEIDINGGEVENDE FUNCTIES BIJ OPENBAAR BESTUUR

I. Aantal werkenden:

- absoluut in 1971: 2.300

1981: 3.400

$1985: 4.400$

- in $\%$ van totaal aantal werkenden: 1971: 0,05

$1981: 0,07$

$1985: 0,09$

II. Aandeel leeftijdsgroepen in totaal aantal werkenden in beroepsklasse $(\%)$ :

$\begin{array}{ll}<30 & \text { jaar } \\ 30-49 & \text { jaar } \\ 50-59 \text { jaar } & \text { jaar }\end{array}$

$\frac{1981}{\#}$

38

35

\#

Indicatoren:

Indicator relatieve vervangingsbehoefte**:

$1981: 3,14$

$1985:$

Gecorrigeerde indicator relatieve vervangingsbehoefte (GIRV)***:

$1981: 4,40$

$1985:$

Indicator absorptiegraad****:

1981: 0,08

$1985: 0,0$

Gecorrigeerde absorptiegraad (GAG)*****:

$1981: 0,12$

$1985: 0,0$

III. Aandeel opleidingscategorieën in totaal aantal werkenden in beroepsklasse (\%):

Universitair opgeleiden

HBO-ers

$\mathrm{MBO}$-ers

LBO-ers

HAVO/VhO-ers

MAVo-ers

Basis onderwijs

\begin{tabular}{l}
1981 \\
\hline 41 \\
$24(1)$ \\
$18(1)$ \\
$\#$ \\
$\#$ \\
$\#$ \\
$\#$
\end{tabular}

$\frac{1985}{37}$

$26(1)$

$19(1)$

$\#$

$\ddagger$

$\#$

$\#$ 
IV. Aandeel werkzame personen bij overheid en overige kwartaire diensten:

1981: $100,0 \%$

\# Te gering aantal of percentage (zie paragraaf 2.2).

(1) Het betreft hier overigens een groep< 1000 personen. 


\section{BELEIDVOERENDE- EN

\section{OPENBAAR BESTUUR)}

I. Aantal werkenden:

- absoluut in 1971: 104.800

1981: 131.900

$1985: 164.900$

- in \% van totaal aantal werkenden: 1971: 2,19

II. Aandeel leeftijdsgroepen in totaal aantal werkenden in beroepsklasse $(\%)$ :

$\begin{array}{ll}<30 & \text { jaar } \\ 30-49 & \text { jaar } \\ 50-59 & \text { jaar } \\ 60-64 & \text { jaar }\end{array}$

\section{$\frac{1981}{7}$}

63

24

6

Indicatoren:

Indicator relatieve vervangingsbehoefte**:

$1981: 1,86$

1985:

Gecorrigeerde indicator relatieve vervangingsbehoefte $($ GIRV) $* * *$ :

$1981: 2,19$

1985:

Indicator absorptiegraad****:

$1981: 0,18$

$1985: 0,15$

Gecorrigeerde absorptiegraad (GAG)*****:

$1981: 0,21$

$1985: 0,18$

III. Aandeel opleidingscategorieën in totaal aantal werkenden in beroepsklasse (\%):

Universitair opgeleiden

$\mathrm{HBO}-\mathrm{ers}$

$\underline{1981}$

$\underline{1985 *}$

5

$\mathrm{MBO}$-ers

LBO-ers

$\mathrm{HAVO} / \mathrm{VkO}$-ers

MAVO-ers

Basis onderwijs 
IV. Aandeel werkzame personen bij overheid en overige kwartaire diensten:

1981: $12,3 \%$

\# Te gering aantal of percentage (zie paragraaf 2.2 ). 


\section{TOEZICHTHOUDEND - EN LEIDINGGEVEND ADMINISTRATIEF PERSONEEL}

I. Aantal werkenden:

- absoluut in 1971: 19.700

1981: 9.500

$1985: 17.500$

- in \% van totaal aantal werkenden: 1971: 0,41

$1981: 0,19$

$1985: 0,34$

II. Aandeel leeftijdsgroepen in totaal aantal werkenden in beroepsklasse (\%):

$\begin{array}{ll}<30 & \text { jaar } \\ 30-49 & \text { jaar } \\ 50-59 & \text { jaar } \\ 60-64 & \text { jaar }\end{array}$

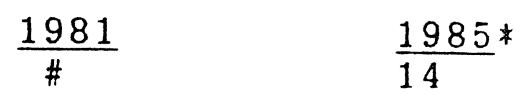

52

33

\#

Indicatoren:

Indicator relatieve vervangingsbehoefte**:

$1981: 2,49$

$1985:$

Gecorrigeerde indicator relatieve vervangingsbehoefte (GIRV)*** :

$1981: 1,15$

$1985:$

Indicator absorptiegraad****:

$1981: 0,25$

$1985: 0,39$

Gecorrigeerde absorptiegraad (GAG)*****:

$1981: 0,26$

$1985: 0,40$

III. Aandeel opleidingscategorieën in totaal aantal werkenden in beroepsklasse $(\%)$ :

Universitair opgeleiden

HBO-ers

MBO-ers

LBO-ers

HAVO/VHO-ers

MAVO-ers

Basis onderiijs

$\begin{array}{rr}1981 & \\ \# & \frac{1985}{\#} \\ 15 & 15 \\ 48 & 50 \\ \# & 8 \\ \# & 10 \\ 15 & 11 \\ \# & \#\end{array}$

IV. Aandeel werkzame personen bij overheid en overige kwartaire diensten:

$1981: 52,6 \%$

\# Te gering aantal of percentage (zie paragraaf 2.2 ). 


\section{UITVOERENDE HOOFDAMBTENAREN}

I. Aantal werkenden:

- absoluut in 1971: 12.100

1981: 16.300

1985: 16.300

- in $\%$ van total aantal werkenden: 1971: 0,25

1981: 0,32

$1985: 0,32$ II. Aandeel leeftijdsgroepen in totaal aantal werkenden in
beroepsklasse $(\%)$ :

$\begin{array}{llcc}<30 & \text { jaar } & \frac{1981}{\#} & \text { 1985* } \\ 30-49 & \text { jaar } & 56 & \# \\ 50-59 \text { jaar } & 31 & \\ 60-64 \text { jaar } & \#\end{array}$

Indicatoren:

Indicator relatieve vervangingsbehoefte**:

$1981: 2,35$

1985 :

Gecorrigeerde indicator relatieve vervangingsbehoefte (GIRV)***:

$1981: 3,01$

$1985:$

Indicator absorptiegraad****:

1981:0,17

$1985: 0,09$

Gecorrigeerde absorptiegraad $(\mathrm{GAG}) * * * * *$ :

1981: 0,24

$1985: 0,12$ III. Aandeel opleidingscategorieën in totaal aantal werkenden in
beroepsklasse $(\%)$ :

$\begin{array}{lcc}\text { Universitair opgeleiden } & \frac{1981}{26} & \frac{1985}{29} \\ \text { HBO-ers } & 37 & 34 \\ \text { MBO-ers } & 28 & 28 \\ \text { LBO-ers } & \# & \# \\ \text { HAVO/VWO-ers } & \# & \# \\ \text { MAVO-ers } & \$ & 7 \\ \text { Basis onderwijs } & \$ & \#\end{array}$

IV. Aandeel werkzame personen bij de overheid en overige kwartaire diensten:

1981: $95,7 \%$

\# Te gering aantal of percentage (zie paragraaf 2.2 ). 
SECRETARESSEN, TYPISTEN, PONSTYPISTENE.D.

I. Aantal werkenden:

- absoluut in 1971: 118.200

1981: 136.800

$1985: 149.200$

- in \% van totaal aantal werkenden: 1971:2,47

$1981: 2,68$

$1985: 2,90$

II. Aandeel leeftijdsgroepen in totaal antal werkenden in beroepsklasse $(\boldsymbol{x})$ :

$\begin{array}{ll}<30 & \text { jaar } \\ 30-49 & \text { jaar } \\ 50-59 & \text { jaar } \\ 60-64 & \text { jaar }\end{array}$

1981

59

$\underline{1985 *}$

$+$

34

6

\#

Indicatoren:

Indicator relatieve vervangingsbehoefte**:

1981: 0,43

1985 :

Gecorrigeerde indicator relatieve vervangingsbehoefte (GIRV)*** :

$1981: 0,47$

$1985:$

Indicator absorptiegraad****:

$1981: 1,61$

$1985: 1,50$

Gecorrigeerde absorptiegraad (GAG)*****:

$1981: 1,61$

$1985: 1,50$

III. Aandeel opleidingscategorieën in totaal aantal werkenden in beroepsklasse (\%):

Universitair opgeleiden

HBO-ers

$\frac{1981}{\#}$

$\mathrm{MBO}-\mathrm{ers}$

13

38

LBO-ers

HAVO/VWO-ers

11

MAVO-ers

Basis onderwijs

9
21

21

5

\begin{tabular}{c}
1985 \\
\hline$\#$ \\
18 \\
37 \\
14 \\
11 \\
15 \\
$\#$
\end{tabular}

IV. Aandeel werkzame personen bij overheid en overige kwartaire diensten:

$1981: 25,1 \%$

\# Te gering aantal of percentage (zie paragraaf 2.2). 


\section{BOEKHOUDERS, KASSIERS EN VERWANTE FUNCTIES}

I. Aantal werkenden:

- absoluut in 1971: 206.300

1981: 276.300

$1985: 295.700$

- in \% van totaal aantal werkenden: 1971:4,31

$1981: 5,41$

$1985: 5,75$

II. Aandeel leeftijdsgroepen in totaal aantal werkenden in beroepsklasse (\%):

$\begin{array}{llccc}<30 & \text { jaar } & \ddots & \frac{1981}{47} & \text { 1985* } \\ 30-49 \text { jaar } & & 38 & \\ 50-59 & \text { jaar } & 12 & \\ 60-64 \text { jaar } & & \#\end{array}$

Indicatoren:

Indicator relatieve vervangingsbehoefte**:

$1981: 0,91$

$1985:$

Gecorrigeerde indicator relatieve vervangingsbehoefte (GIRV)***:

$1981: 1,14$

$1985:$

Indicator absorptiegraad****:

1981: 1,28

$1985: 1,32$

Gecorrigeerde absorptiegraad (GAG)*****:

$1981: 1,23$

$1985: 1,27$

III. Aandeel opleidingscategorieën in total aantal werkenden in beroepsklasse (\%):

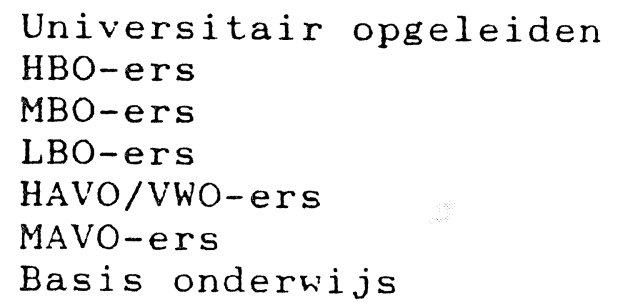

\begin{tabular}{c}
1981 \\
\hline$\#$ \\
6 \\
41 \\
14 \\
12 \\
19 \\
6
\end{tabular}

\begin{tabular}{c}
1985 \\
\hline 5 \\
8 \\
43 \\
14 \\
13 \\
15 \\
$=$
\end{tabular}

IV. Aandeel werkzame personen bij overheid en overige kwartaire diensten:

$1981: 16,4 \%$

\# Te gering aantal of percentage (zie paragraaf 2.2 ). 


\section{DIVERSE ADMINISTRATIEVE FUNCTIES}

I. Aantal werkenden:

- absoluut in 19i1: 304.200

$1981: 409.500$

$1985: 382.500$

- in \% van totaal aantal werkenden: 1971:6,35

$1981: 8,02$

1985: 7,43

II. Aandeel leeftijdsgroepen in totaal aantal werkenden in beroepsklasse $(\%)$ :

$\begin{array}{ll}<30 & \text { jaar } \\ 30-49 & \text { jaar } \\ 50-59 & \text { jaar } \\ 60-64 & \text { jaar }\end{array}$

$\underline{1981}$

$\underline{1985 *}$

44

13

\#

Indicatoren:

Indicator relatieve vervangingsbehoefte**:

$1981: 1,00$

1985 :

Gecorrigeerde indicator relatieve vervangingsbehoefte (GIRV)***:

$1981: 1,26$

$1985:$

Indicator absorptiegraad****:

$1981: 1,20$

$1985: 1,22$

Gecorrigeerde absorptiegraad (GAG)*****:

$1981: 1,14$

$1985: 1,17$

III. Aandeel opleidingscategorieën in totaal aantal werkenden in beroepsklasse (\%):

Universitair opgeleiden

HBO-ers

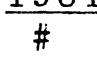

6

$\mathrm{MBO}$-ers

35

LBO-ers

13

$\mathrm{HAVO} / \mathrm{VhO}$-ers

12

MAVO-ers

22

Basis onderwijs

10

\begin{tabular}{c}
1985 \\
\hline$\#$ \\
8 \\
37 \\
14 \\
13 \\
17 \\
7
\end{tabular}

IV. Aandeel werkzame personen bij overheid en overige kwartaire diensten:

1981: $31,3 \%$

\# Te gering aantal of percentage (zie paragraaf 2.2 ). 


\section{DIRECTEUREN EN BEDRIJFSLEIDERS GROOTHANDEL}

I. Aantal werkenden:

- absoluut in 1971: 15.500

1981: 18.200

1985: 30.200

- in \% van total aantal werkenden: 1971:0,32

$1981: 0,36$

$1985: 0,59$

II. Aandeel leeftijdsgroepen in total aantal werkenden in beroepsklasse $(\%)$ :

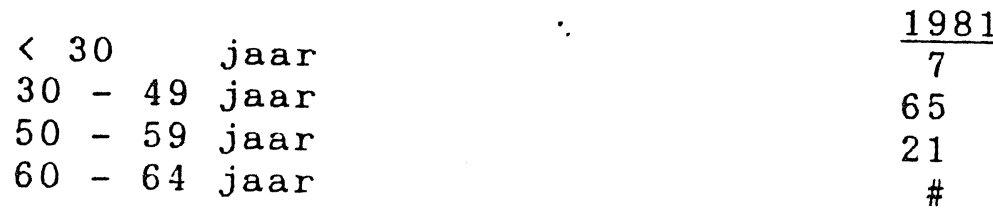

$\frac{1985 *}{5}$

Indicatoren:

Indicator relatieve vervangingsbehoefte**:

1981: 1,65

1985 :

Gecorrigeerde indicator relatieve vervangingsbehoefte (GIRV)***:

1981: 1,86

1985 :

Indicator absorptiegraad****:

$1981: 0,18$

$1985: 0,15$

Gecorrigeerde indicator absorptiegraad (GAG)****:

1981: 0,19

$1985: 0,16$

III. Aandeel opleidingscategorieën in totaal aantal werkenden in beroepsklasse (\%):

Universitair opgeleiden

HBO-ers

MBO-ers

LBO-ers

HAVO/VWO-ers

MAVO-ers

Basis onderwijs

$\begin{array}{rr}\frac{1981}{\#} & \frac{1985}{6} \\ 18 & 17 \\ 39 & 45 \\ 8 & 8 \\ 12 & 9 \\ 10 & 9 \\ 7 & 6\end{array}$

IV. Aandeel werkzame personen bij de overheid en overige kwartaire diensten:

1981: $-\%$

\# Te gering aantal of percentage (zie paragraaf 2.2 ) 


\section{ZELFSTANDIGE GROOTHANDELAREN EN TUSSENPERSONEN}

I. Aantal werkenden:

- absoluut in 1971: 26.600

1981: 26.800

$1985: 21.700$

- in \% van totaal aantal werkenden: 1971:0,56

$1981: 0,52$

$1985: 0,42$

II. Aandeel leeftijdsgroepen in totaal aantal werkenden in beroepsklasse (\%):

$\begin{array}{ll}<30 & \text { jaar } \\ 30-49 & \text { jaar } \\ 50-59 & \text { jaar } \\ 60-64 & \text { jaar }\end{array}$

$\underline{1981}$

11

$1_{1985^{*}}$

Indicatoren:

Indicator relatieve vervangingsbehoefte**:

1981: 1,90

1985 :

Gecorrigeerde indicator relatieve vervangingsbehoefte $($ GIRV) $* * *$ :

1981: 0,93

1985 :

Indicator absorptiegraad****:

1981: 0,30

$1985: 0,39$

Gecorrigeerde indicator absorptiegraad (GAG)*****:

1981: 0,29

$1985: 0,37$

III. Aandeel opleidingscategorieën in totaal aantal werkenden in beroepsklasse $(\%)$ :

Universitair opgeleiden

HBO-ers

$\frac{1981}{\#}$

MBO-ers

6

LBO-ers

HAVO/VWO-ers

MAVO-ers

Basis onderwijs

38

12

7

10

23

$\frac{1985}{\#}$

8

37

14

7

10

20

IV. Aandeel werkzame personen bij de overheid en overige kwartaire diensten:

1981: $-\%$

\# Te gering aantal of percentage (zie paragraaf 2.2 ). 


\section{VERTEGENWOORDIGERS, HANDELSAGENTEN}

I. Aantal werkenden:

- absoluut in 1971: 59.800

1981: 49,500

1985: 50.500

- in \% van total aantal werkenden: 1971: 1,25

$1981: 0,97$

$1985: 0,98$

II. Aandeel leeftijdsgroepen in totaal aantal werkenden in beroepsklasse (\%):

$\begin{array}{lllcc}<30 & \text { jaar } & . & \frac{1981}{19} & \text { 1985* } \\ 30-49 & \text { jaar } & & 62 & 19 \\ 50-59 & \text { jaar } & 16 & \\ 60-64 \text { jaar } & & \#\end{array}$

Indicatoren:

Indicator relatieve vervangingsbehoefte**:

$1981: 1,18$

1985:

Gecorrigeerde indicator relatieve vervangingsbehoefte $(\mathrm{GIRV}) * * *$ :

$1981: 0,92$

1985 :

Indicator absorptiegraad****:

$1981: 0,51$

$1985: 0,54$

Gecorrigeerde indicator absorptiegraad (GAG)*****:

$1981: 0,51$

$1985: 0,55$

III. Aandeel opleidingscategorieën in totaal aantal werkenden in beroepsklasse $(\%)$ :

Universitair opgeleiden

HBO-ers

MBO-ers

LBO-ers

HAVO/VWO-ers

MAVO-ers

Basis onderwijs

$\begin{array}{rr}\frac{1981}{\#} & \frac{1985}{\hbar} \\ 11 & 15 \\ 49 & 51 \\ 14 & 11 \\ 6 & 6 \\ 10 & 10 \\ 8 & 6\end{array}$

IV. Aandeel werkzame personen bij de overheid en overige liwartaire diensten:

$1981: 0,2 \%$

\# Te gering aantal of percentage (zie paragraaf 2.2). 
VERZEKERINGSAGENTEN, MAKELAARS,

\section{TUSSENPERSONEN}

I. Aantal werkenden:

- absoluut in 1971: 28.100

1981: 34.100

$1985: 34.600$

- in \% van totaal aantal werkenden: 1971: 0,59

1981:0,67

$1985: 0,67$

II. Aandeel leeftijdsgroepen in totaal aantal werkenden in beroepsklasse (\%):

$\begin{array}{ll}<30 & \text { jaar } \\ 30-49 & \text { jaar } \\ 50-59 & \text { jaar } \\ 60-64 & \text { jaar }\end{array}$

1981

$\frac{1985 *}{22}$

55

19

5

Indicatoren:

Indicator relatieve vervangingsbehoefte**:

$1981: 1,50$

1985:

Gecorrigeerde indicator relatieve vervangingsbehoefte (GIRI) *** :

$1981: 1,70$

1985 :

Indicator absorptiegraad ****:

$1981: 0,53$

$1985: 0,62$

Gecorrigeerde indicator absorptiegraad*****:

$1981: 0,55$

$1985: 0,61$

III. Aandeel opleidingscategorieën in totaal aantal werkenden in beroepsklasse $(\%)$ :

Universitair opgeleiden

HBO-ers

$\mathrm{MBO}$-ers

LBO-ers

HAVO/VWO-ers

MAVO-ers

Basis onderwijs

$\begin{array}{cc}\frac{1981}{\#} & \frac{1985}{\#} \\ 11 & 16 \\ 60 & 60 \\ \# & 5 \\ 9 & 7 \\ 9 & 7 \\ \# & \neq\end{array}$


IV. Aandeel werkzame personen bij overheid en overige kwartaire diensten:

$1981: 5,6 \%$

\# Te gering aantal of percentage (zie paragraaf 2.2). 


\section{DIVERSE DIENSTVERLENENDE FUNCTIES}

I. Aantal werkenden:

- absoluut in 1971: 22.400

$1981: 29.600$

$1985: 29.700$

- in \% van totaal aantal werkenden: 1971:0,47

$1981: 0,58$

$1985: 0,58$

II. Aandeel leeftijdsgroepen in totaal aantal werkenden in beroepsklasse $(\boldsymbol{x})$ :

$\begin{array}{ll}<30 & \text { jaar } \\ 30-49 & \text { jaar } \\ 50-59 & \text { jaar } \\ 60-64 \text { jaar }\end{array}$

1981

51

$\underline{1985 *}$

Indicatoren:

Indicator relatieve vervangingsbehoefte**:

$1981: 1,08$

$1985:$

Gecorrigeerde indicator relatieve vervangingsbehoefte (GIRI) ***:

$1981: 1,33$

$1985:$

Indicator absorptiegraad****:

$1981: 1,39$

$1985: 1,36$

Gecorrigeerde indicator absorptiegraad (GAG)*****:

$1981: 1,32$

$1985: 1,46$

III. Aandeel opleidingscategorieën in totaal aantal werkenden in beroepsklasse (\%):

Universitair opgeleiden

HBO-ers

$\mathrm{MBO}-\mathrm{ers}$

30

15

48

LBO-ers

$\mathrm{HAVO} / \mathrm{VWO}$-ers

MAVO-ers

Basis onderiijs

\begin{tabular}{c}
1981 \\
\hline$\#$ \\
$\#$ \\
43 \\
12 \\
7 \\
13 \\
17
\end{tabular}

IV. Aandeel werkzame personen bij overheid en overige kwartaire diensten:

$1981: 16,2 \%$

\# Te gering aantal of percentage (zie paragraaf 2.2 ). 


\section{TOEZICHTHOUDEND EN LEIDINGGEVEND PRODUKTIEPERSONEEL}

I. Aantal werkenden:

- absoluut in 1971: 104.100

1981: 73.200

1985: 100.500

- in \% van total aantal werkenden: 1971:2,17

1981: 1,43

$1985: 1,95$

II. Aandeel leeftijdsgroepen in total aantal werkenden in beroepsklasse (\%):

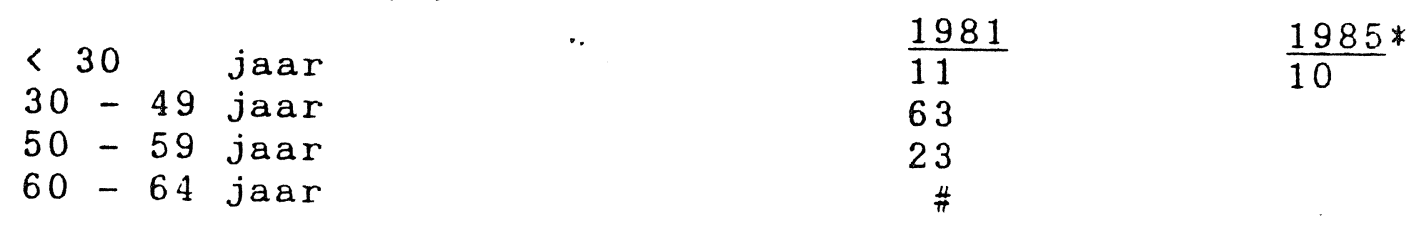

Indicatoren:

Indicator relatieve vervangingsbehoefte**:

$1981: 1,67$

1985:

Gecorrigeerde indicator relatieve vervangingsbehoefte (GIRV) *** :

1981: 1,10

1985 :

Indicator absorptiegraad****:

1981:0,29

$1985: 0,29$

1.. Gecorrigeerde indicator absorptiegraad (GAG)*****:

$1981: 0,28$

$1985: 0,28$

II . Aandeel opleidingscategorieën in totaal aantal werkenden in beroepsklasse $(\%)$ :

Universitair opgeleiden

HBO-ers

$\begin{array}{rr}\frac{1981}{\#} & \frac{1985}{\#} \\ 5 & 8 \\ 52 & 55 \\ 22 & 20 \\ \# & \# \\ \# & \# \\ 14 & 11\end{array}$

IV. Aandeel werkenden personen bij overheid en overige kwartaire diensten:

$1981: 2,1 \%$

\# Te gering aantal of percentage (zie paragraaf 2.2 ). 


\section{THEOLOGEN}

I. Aantal werkenden:

- absoluut in 19i1: 9.300

$1981: 8.700$

$1985: 9.900$

- in \% van totaal aantal werkenden: 1971: 0,19

1981: 0,17

$1985: 0,19$

II. Aandeel leeftijdsgroepen in totaal antal werkenden in beroepsklasse $(\%)$ :

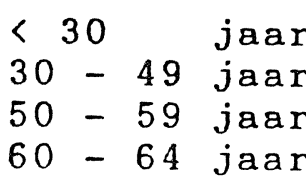

$\frac{1981}{\#}$
43
32
12

Indicatoren:

Indicator relatieve vervangingsbehoefte**:

$1981: 2,75$

1985:

Gecorrigeerde indicator relatieve vervangingsbehoefte $($ GIRV)***:

$1981: 2,46$

$1985:$

Indicator absorptiegraad****:

$1981: 0,19$

$1985: 0,23$

Gecorrigeerde indicator absorptiegraad (GAG)*****:

$1981: 0,29$

$1985: 0,37$

III. Aandeel opleidingscategorieën in totaal aantal werkenden in beroepsklasse $(\%)$ :

Universitair opgeleiden

HBO-ers

MBO-ers

LBO-ers

$\mathrm{HAVO} / \mathrm{VKO}$-ers

MAVO-ers

Basis onderwijs

$\begin{array}{cc}1981 & \frac{1985}{48} \\ 35 & 59 \\ \# & 31 \\ \# & \# \\ \# & \# \\ \# & \# \\ \# & \#\end{array}$

IV. Aandeel werkenden personen bij overheid en orerige kwartaire diensten:

$1981: 95,4 \%$

\# Te gering aantal of percentage (zie paragraaf 2.2 ). 
BI JLAGE III

ARBEIDSMARKTDATA MET BETREKKING TOT ENKELE SPECIFIEKE BEROEPSGROEPEN

Bron: $\mathrm{CBS} / \mathrm{ROA}$ 
- Scheikundigen

- Natuurkundigen (drs. en ir.)

- Schei-, natuurkundige analisten, geologische assistenten e.d.

- Hogere elektrotechnici, elektronici

- Hoofden technische dienst (hoger)

- Hogere werktuigbouwkundigen.

- Hogere chemisch technologen

- Hogere technisch natuurkundigen en metaalkundigen

- Bedrijfskundigen en verwante functies

- Biologen, zoblogen, botanici e.d.

- Hogere biochemici, bacteriologen, farmacologen e.d.

- Botanische, medische e.d. analisten, landbouwkundige assistenten e.d.

- Geneeskundigen

- Tandheelkundigen

- Diergeneeskundigen

- Hogere statistici

- Wiskundigen, actuarissen

- Systeemanalisten e.a. automatiseringsdeskundigen

- Economen

- Juristen

- Accountants

- Leerkrachten

- Auteurs, recensenten

- Journalisten e.d.

- Sociologen, psychologen e.a. sociale wetenschapsbeoefenaren

- Personeels-, beroepenspecialisten en -adviseurs

- Taalkundigen, vertalers en tolken

- Beleidvoerende en hogere leidinggevende functies (exclusief openbaar bestuur)

- Uitvoerende hoofdambtenaren

\begin{tabular}{|c|c|}
\hline $\begin{array}{l}\text { Beroepen } \\
\text { classifica- } \\
\text { tie-code* } \\
011 \\
\quad 0.12\end{array}$ & $\begin{array}{c}\text { bladzi jde } \\
3 \\
4\end{array}$ \\
\hline $\begin{array}{l}014 \\
023 \\
024 \\
025 \\
026\end{array}$ & $\begin{array}{l}5 \\
6 \\
7 \\
8 \\
9\end{array}$ \\
\hline $\begin{array}{l}027 \\
028 \\
051\end{array}$ & $\begin{array}{l}10 \\
11 \\
12\end{array}$ \\
\hline 052 & 13 \\
\hline $\begin{array}{l}054 \\
061 \\
063 \\
065 \\
081 \\
082\end{array}$ & $\begin{array}{l}14 \\
15 \\
16 \\
17 \\
18 \\
19\end{array}$ \\
\hline $\begin{array}{l}083 \\
090 \\
120 \\
110 \\
130 \\
151 \\
159\end{array}$ & $\begin{array}{l}20 \\
21 \\
23 \\
22 \\
24 \\
25 \\
26\end{array}$ \\
\hline 192 & 27 \\
\hline $\begin{array}{l}194 \\
195\end{array}$ & $\begin{array}{l}28 \\
28\end{array}$ \\
\hline $\begin{array}{l}210 \\
310\end{array}$ & $\begin{array}{l}30 \\
31\end{array}$ \\
\hline
\end{tabular}




\section{SCHEIKUNDIGEN}

I. Aantal werkenden

- absoluut 1971: 1.900

1981: 3.900

$1983: 1.200$

$1985: 2.600$

- aandeel in totaal aantal werkenden (\%) 1971:0,04

$1981: 0,08$

$1983: 0,02$

$1985: 0,05$ 
NATUURKUNDIGEN (drs, en ir.)

I. Aantal werkenden

- absoluut 1971: 900

1981: 1.900

1983: 1.500

$1985: 1.500$

- aandeel in totaal aantal werkenden (\%) 1971:0,02 1981: 0,04 $1983: 0,03$ 1985: 0,03 
SCHEI-, NATUURKUNDIGE ANALISTEN, GEOLOGISCHE ASSISTENTEN E.D.

I. Aantal werkenden

- absoluut 1971:23.600

$1981: 26.600$

$1983: 26.900$

$1985: 28.800$

- aandeel in totaal aantal werkenden (\%) 1971:0,49

$1981: 0,52$

$1983: 0,59$

$1985: 0,56$ 


\section{HOGERE ELEKTROTECHNICI， ELEKTRONICI}

I. Aantal werkenden

- absoluut 1971: 6.300

1981: 10.400

1983: 5.400

1985: 8.300

- aandeel in total aantal werkenden (\%) 1971:0,13

1981: 0,20

$1983: 0,11$

$1985: 0,16$ 
HOOFDEN TECHNISCHE DIENST (hoger)

I. Aantal werkenden

- absoluut 1971: 1.000

1981: 2.200

$1983: 2.900$

$1985: 2.300$

- aandeel in totaal aantal werkenden (\%) 1971:0,02 $1981: 0,04$ $1983: 0,06$ $1985: 0,04$ 


\section{HOGERE WERKTUIGBOUWKUNDIGEN}

I. Aantal werkenden

- absoluut 1971: 9.200

1981: 12.300

1983: 11.100

1985: 12.700

- andeel in totaal aantal werkenden (\%) 1971:0,19 $1981: 0,24$ $1983: 0,22$ $1985: 0,25$ 


\section{HOGERE CHEMISCHE TECHNOLOGEN}

I. Aantal werkenden

- absoluut 1971: 3.000

1981: 3.500

$1983: 3.500$

$1985: 5.400$

- aandeel in totaal aantal werkenden (\%) 1971:0,06

$1981: 0,07$

$1983: 0,07$

$1985: 0,10$ 
HOGERE TECHNISCH NATUURKUNDIGEN, METAALKUNDIGEN

I. Aantal werkenden

- absoluut 1971: 1.200

1981: 1.100

1983: 1.200

1985: 1.500

- aandeel in totaal aantal werkenden (\%) 1971:0,03 1981: 0,02 1983: 0,02 $1985: 0,03$ 


\section{BEDRIJFSKUNDIGEN EN VERWANTE FUNCTIES}

I. Aantal werkenden

- absoluut 1971: 17.300

$1981: 24.700$

$1983: 23.500$

$1985: 28.700$

- aandeel in totaal aantal werkenden (\%) 1971:0,36 $1981: 0,48$ $1983: 0,47$ $1985: 0,56$ 
BIOLOGEN, ZOOLOGEN, BOTANICI E.D.

I. Aantal werkenden

- absoluut 1971: 800

1981:2.000

1983: 1.300

$1985: 2.900$

- andeel in totaal aantal werkenden (\%) 1971:0,02

$1981: 0,04$

$1983: 0,03$

1985: 0,06 
HOGERE BIOCHEMICI, BACTERIOLOGEN, FARMACOLOGEN E.D.

I. Aantal werkenden

- absoluut 1971: 1.900

1981: 2.800

$1983: 1.600$

$1985: 2.600$

- aandeel in totaal aantal werkenden (\%) 1971:0,04 $1981: 0,05$

$1983: 0,03$

$1985: 0,05$ 

BOTANISCHE, MEDISCHE E.D. ANALISTEN, LANDBOUWKUNDIGE ASSISTENTEN
E.D.

I. Aantal werkenden

- absoluut 1971: 13.200

1981: 18.900

$1983: 19.300$

1985: 20.300

- aandeel in total aantal werkenden (\%) 1971:0,28

$1981: 0,37$

$1983: 0,39$

$1985: 0,39$ 


\section{GENEESKUNDIGEN}

I. Aantal werkenden

- absoluut 1971: 15.000

1981: 22.600

$1983: 23.900$

1985: 25.100

- aandeel in totaal aantal werkenden (\%) 1971:0,31

$1981: 0,44$

$1983: 0,48$

$1985: 0,49$ 


\section{TANDHEELKUNDIGEN}

I. Aantal werkenden

- absoluut 1971: 3.100

1981: 5.200

$1983: 5.600$

$1985: 4.800$

- aandeel in totaal aantal werkenden (\%) 1971:0,06 1981: 0,10 1983: 0,11 1985: 0,09 


\section{DIERGENEESKUNDIGEN}

I. Aantal werkenden

- absoluut 1971: 1.400

1981: 1.900

$1983: 1.800$

1985: 2.200

- andeel in totaal aantal werkenden (\%) 1971:0,03

1981: 0,04

$1983: 0,04$

$1985: 0,04$ 
HOGERE STATISTICI

I. Aantal werkenden

- absoluut 1971:500

1981: 400

1983: 400

1985: 500

- aandeel in totaal aantal werkenden (\%) 1971: 0,01

1981: 0,01

$1983: 0,01$

1985: 0,01 
WISKUNDIGEN, ACTUARISSEN

I. Aantal werkenden

- absoluut 1971: 600

1981: 1.200

1983: 600

$1985: 1.200$

- andeel in totaal aantal werkenden (x) 1971:0,01 1981: 0,02 $1983: 0,01$ 1985: 0,02 
SYSTEEMANALISTEN E.A. AUTOMATISERINGSDESKUNDIGEN

I. Aantal werkenden

- absoluut 1971: 6.700

1981: 17.700

1983: 21.300

1985: 26.900

- aandeel in totaal aantal werkenden (\%) 1971:0,14 $1981: 0,35$

$1983: 0,43$

$1985: 0,52$ 


\section{ECONOMEN}

I. Aantal werkenden

- absoluut 1971: 7.500

$1981: 13.700$

$1983: 14.300$

$1985: 15.200$

- aandeel in totaal aantal werkenden (\%) 1971: 0,16

$1981: 0,27$

$1983: 0,29$

$1985: 0,30$ 


\section{ACCOUNTANTS}

I. Aantal werkenden

- absoluut 1971: 7.900

1981: 14.100

$1983: 14.200$

1985: 12.500

- aandeel in totaal aantal werkenden (\%) 1971:0,16 1981: 0,28 $1983: 0,28$ $1985: 0,24$ 


\section{$\underline{\text { JURISTEN }}$}

I. Aantal werkenden

- absoluut 1971: 7.000

1981: 14.500

$1983: 17.200$

$1985: 18.700$

- aandeel in totaal aantal werkenden (\%) 1971:0,15 1981: 0,28

1983: 0,34

$1985: 0,36$ 


\section{LEERKRACHTEN}

I. Aantal werkenden

- absoluut 1971: 156.700

1981: 265.200

$1983: 272.500$

1985: 276.000

- aandeel in totaal aantal werkenden (\%) 1971: 3,27 $1981: 5,19$ $1983: 5,44$ $1985: 5,37$ 


\section{AUTEURS, RECENSENTEN}

I. Aantal werkenden

- absoluut 1971:500

1981: 900

1983: 800

1985: 700

- aandeel in totaal aantal werkenden ( $\%$ ) 1971:0,01

1981: 0,02

$1983: 0,02$

$1985: 0,01$ 
JOURNALISTEN E.D.

I. Aantal werkenden

- absoluut 1971: 7.300

1981: 16.300

1983: 16.100

1985: 19.400

- aandeel in totaal aantal werkenden

(\%) $1971: 0,15$

1981: 0,32

$1983: 0,32$

$1985: 0,38$ 
SOCIOLOGEN, PSYCHOLOGEN E.A. SOCIALE WETENSCHAPSBEOEFENAREN

I. Aantal werkenden

- absoluut 1971: 5.700

$1981: 19.700$

$1983: 19.000$

$1985: 24.100$

- aandeel in totaal aantal werkenden (\%) 1971:0,12

$1981: 0,39$

$1983: 0,38$

$1985: 0,47$ 


\section{PERSONEELS-, BEROEPENSPECIALISTEN EN -ADVISEURS}

I. Aantal werkenden

- absoluut 1971: 5.400

1981: 11.100

$1983: 12.300$

$1985: 11.000$

- aandeel in totaal aantal werkenden (\%) 1971: 0,11

1981: 0,22

$1983: 0,25$

1985: 0,21 


\section{TAALKUNDIGEN, VERTALERS EN TOLKEN}

I. Aantal werkenden

- absoluut 1971: 1.800

1981: 4.300

$1983: 5.100$

$1985: 3.600$

- aandeel in totaal aantal werkenden (\%) 1971: 0,04

1981: 0,08

$1983: 0,10$

$1985: 0,07$ 

OPENBAAR BESTUUR)*

I. Aantal werkenden

- absoluut 1971: 104.800

$1981: 131.900$

$1983: 155.700$

$1985: 164.900$

- aandeel in total aantal werkenden (\%) $1971: 2,19$
$1981: 2,58$
$1983: 3,11$
$1985: 3,21$

* De belangrijkste in deze beroepsgroep werkzame opleidingscategorieën: economen, technisch geschoolden, juristen en bestuurskundigen en sociale wetenschappers. 


\section{UITVOERENDE HOOFDAMBTENAREN**}

I. Aantal werkenden

- absoluut 1971: 12.100

1981: 16.300

$1983: 19.100$

$1985: 16.300$

- andeel in totaal aantal werkenden (\%) 1971:0,25

$1981: 0,32$

1983: 0,38

$1985: 0,32$

* De belangrijkste in deze beroepsgroep werkzame opleidingscategorieën: juristen en bestuurskundigen en sociale wetenschappers. 